\title{
Natural Polymeric Materials: A Solution to Plastic Pollution from the Agro-Food Sector
}

\author{
Maria Assunta Acquavia ${ }^{1,2}$, Raffaella Pascale ${ }^{3} \mathbb{}$, Giuseppe Martelli ${ }^{1}$, Marcella Bondoni ${ }^{2}$ and \\ Giuliana Bianco $1, * \mathbb{D}$ \\ 1 Dipartimento di Scienze, Università degli Studi della Basilicata, Via dell'Ateneo Lucano, \\ 10-85100 Potenza, Italy; maria.acquavia@unibas.it (M.A.A.); giuseppe.martelli@unibas.it (G.M.) \\ 2 ALMAGISI s.r.l Corso Italia, 27-39100 Bolzano, Italy; m.bondoni@almacabio.com \\ 3 Gnosis by Lesaffre, Pisticci, 75015 Matera, Italy; raff.pascale@gmail.com \\ * Correspondence: giuliana.bianco@unibas.it; Tel.: +39-0971205451
}

Citation: Acquavia, M.A.; Pascale, R.; Martelli, G.; Bondoni, M.; Bianco, G. Natural Polymeric Materials: A Solution to Plastic Pollution from the Agro-Food Sector. Polymers 2021, 13, 158. https://doi.org/10.3390/ polym13010158

Received: 16 December 2020 Accepted: 30 December 2020 Published: 4 January 2021

Publisher's Note: MDPI stays neutral with regard to jurisdictional clai$\mathrm{ms}$ in published maps and institutional affiliations.

Copyright: (C) 2021 by the authors. Licensee MDPI, Basel, Switzerland. This article is an open access article distributed under the terms and conditions of the Creative Commons Attribution (CC BY) license (https:// creativecommons.org/licenses/by/ $4.0 /)$.

\begin{abstract}
Conventional petroleum-derived plastics represent a serious problem for global pollution because, when discarded in the environment, are believed to remain for hundreds of years. In order to reduce dependence on fossil resources, bioplastic materials are being proposed as safer alternatives. Bioplastics are bio-based and/or biodegradable materials, typically derived from renewable sources. Food waste as feedstock represents one of the recent applications in the research field of bioplastics production. To date, several food wastes have been used as raw materials for the production of bioplastics, including mostly fruit and vegetable wastes. The conversion of fruit and vegetable wastes into biomaterials could occur through simple or more complex processes. In some cases, biopolymers extracted from raw biomass are directly manufactured; on the other hand, the extracted biopolymers could be reinforced or used as reinforcing agents and/or natural fillers in order to obtain biocomposites. The present review covers available results on the application of methods used in the last 10 years for the design of biomaterials obtained from formulations made up with both fruits and vegetables by-products. Particular attention will be addressed to the waste pre-treatment, to the bioplastic formulation and to its processing, as well as to the mechanical and physical properties of the obtained materials.
\end{abstract}

Keywords: plastic pollution; bioplastics; biocomposites; fruits and vegetables waste

\section{Introduction}

Over the last 50 years, the global production of synthetic plastics, which are carbonbased polymers such as polypropylene, polyethylene, polyvinyl chloride, polystyrene, nylon, and polycarbonate, has continuously increased and it is expected to double in the next 20 years. Approximately 360 million tons of plastics were produced in 2018 and 17\% of it has been produced in Europe [1]. Conventional plastics play a pivotal role in modern society, since they can be readily manufactured to an expanding range of products used in civil and industrial applications thanks to their light weight, flexibility, and durability [2]. However, the huge amount of plastic waste production is one of the most-faced issues over the world both for environmental problems and human health threat [3].

Traditional plastics are almost completely derived from petrochemicals, meaning that fossil feedstocks are used in their production $[4,5]$. Around $80 \%$ of nonfuel chemicals produced by the petrochemical industry are sold for the manufacturing of plastics, thus contributing to environmental pollution as the extraction of oil and gas, particularly hydraulic fracturing for natural gas, releases an array of toxic substances into the air and water, often in significant volumes [5-8]. Furthermore, at the end of the 20th century, plastics were found to be persistent pollutants in many environmental niches, since they are largely non-biodegradable; therefore, once they reach the environment in the form of macro or microplastics, contamination and accumulation in food chains through agricultural land, 
terrestrial, and aquatic food chains and water supply could happen. Plastics spread in the environment could easily leach toxic additives or hazardous substances, for example, phthalates, brominated flame retardants, bisphenol A, formaldehyde, acetaldehyde, 4nonylphenol, and many volatile organic compounds, making them bioavailable again for direct or indirect human exposure $[9,10]$. Toxic chemicals that enter the human body through microplastics ingestion can lead to several health impacts, including reduced feeding, blocking of the intestinal tract responsible for starvation and impaired bodily functioning, and translocation to the circulatory system [11].

At the end of their life-cycle, plastics product are disposed of by dumping in landfills, by burning in incinerators, or by littering. In the case of littering, plastic wastes fail to reach landfills or incinerators. This is an improper way of disposing plastics and is identified as the cause of manifold ecological problems. Incineration of plastic wastes significantly reduces the volume of waste requiring disposal. It is believed that the volume reduction brought about by incineration ranges from 80 to $95 \%$. However, their burning releases toxic heavy metals and emits noxious gasses like dioxins and furans [12].

Recycling could be thought of as a good way to reduce plastic pollution, as the cost and the GHG emission can be further reduced by implementing optimization strategies [13], however to date it has been less successful due to difficulties in identification and sorting and the presence of various other materials and additives such as fillers and plasticizers which make the process really expensive [14]. As a result, of all the plastic waste generated, the European average of that collected for recycling is only $30 \%$, with very large differences from country to country [1].

In order to deal with the negative effects of plastic pollution, the European Parliament has developed measures aiming at reducing the quantities of plastic waste, approving a new law banning in EU single-use plastic items such as plates, cutlery, straws, and cotton bud sticks, by 2021. As a consequence, many efforts are being made in the scientific world to found bio-based alternatives which could potentially replace them. This has led to the development of a rich and diversified field of research in bioplastic production [15]. Bioplastic materials are obtained from renewable resources and could be biodegradable and/or compostable. The bioplastic aim is to emulate the life cycle of biomass, which includes conservation of fossil resources, $\mathrm{CO}_{2}$ production, and water [16]. Bio-based resources are expected to play a key role in the production of novel and bio-based materials, contributing to a reduction of the negative environmental impacts of fossil-based products and thus addressing the bioeconomy of the future [17]. The molecular complexity of plant and bacterial biomass provides a wealth of natural bio-based polymers as well as monomeric feedstocks for bioplastic production. Currently, most bioplastics are produced from agricultural crop-based feedstocks (carbohydrates and plant materials). These, however, are not yet ideally aligned with sustainable development goals (SDGs), due to their competition for arable land, fresh water, and food production [18]. Among the countless renewable biomass sources, food waste (FW) has also received particular attention for biodegradable materials production. The possibility to overcome the problems associated to FW disposal, through its reuse for the manufacturing of bio-based plastics with a reduced carbon footprint, is considered as an attractive proposition in the field of green chemistry.

Recently, several reviews have been published relating to the production of bioplastics starting from food waste [19-22]. A discussion on economic viability of FW valorization has been offered by Tsang et al. [19], which also reviewed the technologies commonly employed for the production of polyhydroxyalkanoates. Instead, Maraveas et al. [21] gathered on the general aspects of the synthesis of bio-based polymers from agricultural wastes, as well as on their applications. The main steps in the process of biodegradable films elaboration starting from fruit puree were investigated by Matheus et al. [22], especially lingering on the evaluation of the functional properties of the obtained materials, i.e., the antimicrobial and antioxidant properties.

The search for green formulations that can be suitably manufactured for the production of eco-friendly materials is mandatory in the field of green chemistry and environmental 
sciences. In this review, we will highlight the developments in the application of the methods used over the past decade for the design of biomaterials. Although several reviews discuss on the same topic, here particular emphasis will be given to those obtained from formulations based on fruit and vegetable by-products. In detail, this review represents a comprehensive basis for scientists to direct their research towards natural sources of biopolymers that could be used appropriately for the production of bio-based materials, including cellulose, starch, pectin, cutin-based materials, and biocomposites. A first part will be dedicated to a complete description of the classification systems of bioplastics and to the methods that are commonly used to define their bio-content and biodegradability, as well as their main physical and mechanical properties. Then, a critical discussion on the latest research results concerning bioplastic production from by-products and waste materials of the fruit and vegetable industries made in the last 10 years will be conducted. A summary table (Table A1), containing all the information relating to the pre-processing of the waste, the definition of the green plastic formulation, and the type of manufacturing, as well as the properties of the final material, will be provided.

\section{Bioplastics: Definition and Classification}

According to the European Bioplastics Organization (EBO), a material could be defined as a bioplastic if it is either bio-based, biodegradable, or features both properties [23]. The term bio-based refers to materials or products that are completely or partly derived from renewable resources (biomass); thus the petrochemical resin typical of common plastics is replaced by vegetable or animal polymers and the compounds like glass or carbon fiber or talc are replaced by natural fibers (wood fibers, hemp, flax, sisal, jute) [15]. For those concerning biodegradability, a material could be defined as biodegradable if it undergoes degradation by biological processes during composting to yield carbon dioxide, water, inorganic compounds, and biomass at a rate consistent with those of other known, compostable materials and leaves no other distinguishable or toxic residue [24].

To date, several classification systems based on different criteria have been proposed to distinguish bioplastic materials, as they can show a wide variation in biodegradability percentage and can be derived from a large number of renewable or non-renewable sources [15,25-27].

Bioplastics could be grouped according to their biodegradability and bio-based content in: bio-based (or partly bio-based) but non-biodegradable plastics (or drop-in bioplastics); biodegradable and bio-based plastics and biodegradable plastics based on fossil sources (Figure 1) [23].

Non-biodegradable bioplastics are obtained from renewable sources and they are comparable to classical plastics for the time needed for their complete environmental degradation. This group of plastics are named "drop-in" bioplastics [28] and nowadays represent one of the largest sectors of the global bioplastics production. Bio-PET (biopolyethylene terephthalate) represents a very common drop-in bioplastic example. For PET production, an esterification reaction between terephtalic acid (PTA) and ethylene glycol (EG) followed by a polymerization through a polycondensation reaction with water as by-product is used [29]. In the traditional production of PET, both PTA and EG are fossil refinery products: petroleum refiners first separate out para-xylene (PX) from BTX (Benzene, Toluene, Xylene) mixtures by crystallization method and then oxidize it to PTA. Similarly, in order to obtain EG, ethylene derived from the alkene co-products of natural gas production are processed through hydration and oxidation [30]. For bio-PET, instead, EG or both monomers are obtained from renewable sources by a process identical to that used for petro-PET and also their technical properties are identical to those of their fossil counterparts [31]. Ethylene glycol is always available on a large scale from biomass: at the beginning cellulose recovered from lignocellulosic biomass is converted into xylitol and sorbitol, which are easily hydrolyzed to EG in the presence of several mono- and bimetallic phosphide catalysts $[32,33]$. Moreover, bio-ethanol derived from sugar cane or corn stover and glycerol, as a co-product of biodiesel, have been used as a feedstock to 
produce EG [34]. The production of terephtalic acid by green chemistry processes based on the use of chemical precursors extracted from corn, sugar beet, or orange peel, i.e., isobutanol, 5-hydroxymethylfurfural, and limonene, respectively, is used to a smaller extent [31].

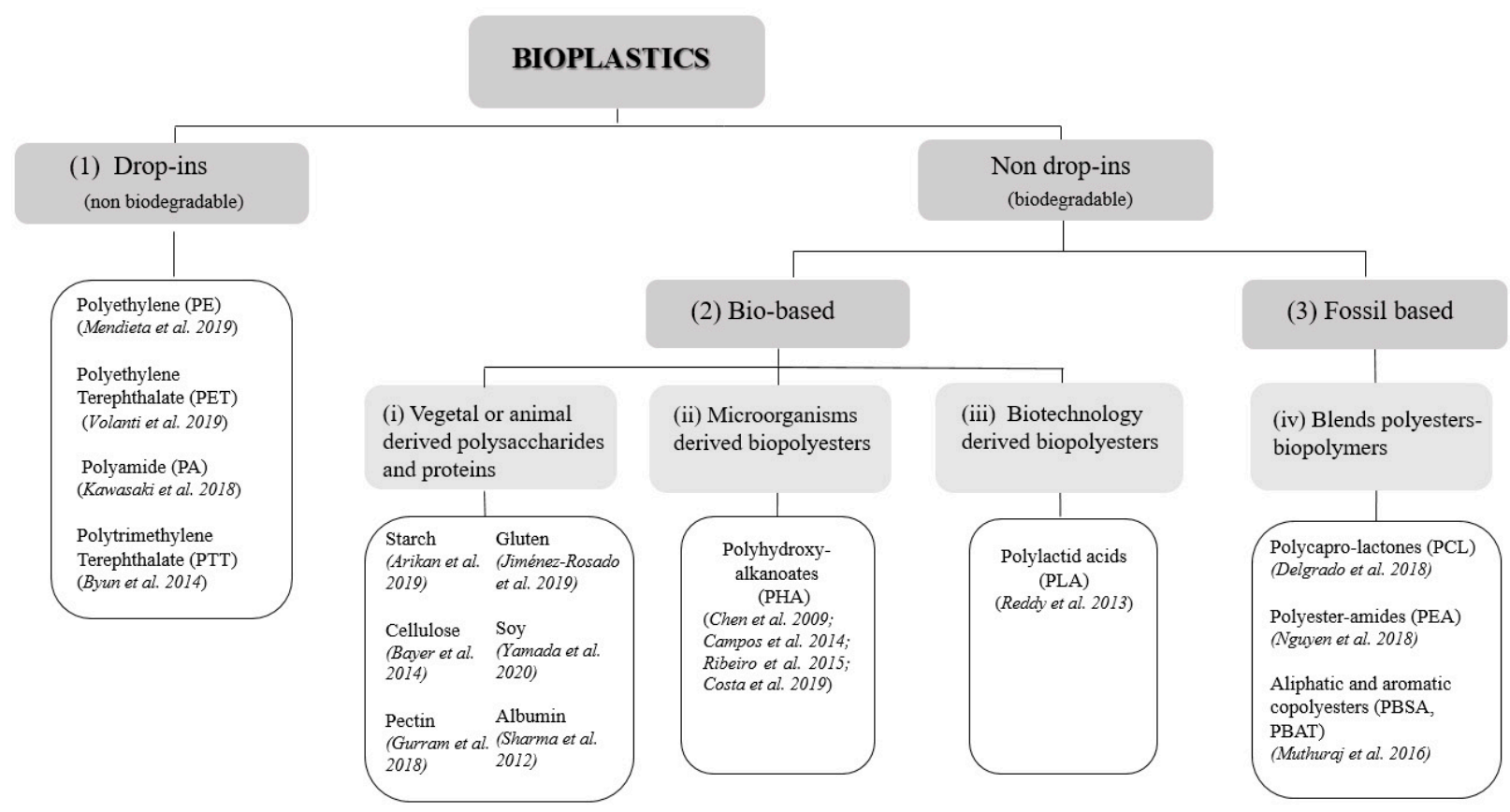

Figure 1. Scheme of bioplastics classification: (1) Drop-in bioplastics (i.e., bio-based or partly bio-based but nonbiodegradable plastics), (2) bio-based non drop-in bioplastics, and (3) fossil based non drop-in bioplastics. According to their origin, non-drop-ins (i.e., biodegradable plastics) are divided into (i) vegetal or animal derived polysaccharides and proteins, (ii) polymers from microorganism, (iii) polymers from biotechnology, and (iv) blends of biopolymers and commercial polyesters [25].

While drop-ins are well known on the market, non-drop-in bioplastics, i.e., plastics that are biodegradable bio-based or based on fossil sources, are alternative materials usually used in niche fields, for example for food services, agriculture, or biomedical applications; therefore, their trade has been emerging only in recent years $[28,35,36]$. These biodegradable polymers can be classified, according to their origin, into four major categories, namely (i) agro-polymers, (ii) polymers from microorganism, (iii) polymers from biotechnology, and (iv) blend of biopolymer and commercial polyesters [15] (Figure 1).

Starch, cellulose, pectin as well as animal and vegetable proteins, such as casein and gluten, are well known for being feedstock of agro-polymers based bioplastics [37-39]. Starch, cellulose, and pectin are polysaccharides that can be extracted from several vegetables and fruits (potato, corn, rice, tapioca, apple) and they are used mainly to produce packaging materials [15]. Often, protein additives are used in order to fabricate materials with novel or improved technological properties. In fact, due to the difference between the elemental composition of proteins (covalent bonds between hundreds of amino acids) and polysaccharides (covalent bonds between monosaccharides with ramifications), their mixtures can evidence a wide variety of two- and three-dimensional structures with different physicochemical and rheological properties [40].

In addition, there are a lot of polymers that could be produced by a range of microorganisms, cultured under different nutrient and environmental conditions [41]. Polyhydroxyalkanoates (PHAs), for example, are linear thermoplastic polymers, with hydroxyalkanoic acid as a monomer unit, which can be synthesized intracellularly as insoluble cytoplasmic inclusions by heterotrophic bacteria, such as Cupriavidus necator [42,43], recombinant Escherichia coli [44], and also by photoautotrophic microorganisms like microalgae [45]. Their 
synthesis occurs in the presence of an excess of carbon, when other essential nutrients such as oxygen, phosphorus, or nitrogen are limited; after their extraction from cell cultures, they can be processed in a similar way to that of polypropylene, including extrusion and injection molding, obtaining a material with similar properties as well.

On the other hand, bacterial microorganisms can also be used to produce, in a biotechnological approach, biodegradable polymers through the fermentation of carbohydrates obtained from agricultural by-products such as starchy substances as corn, wheat, or sugar and corn starch. Poly Lactic Acid (PLA)-based bioplastics are obtained from a fermentative process that involves conversion of corn, or other carbohydrate sources into dextrose, followed by fermentation/conversion into lactic acid [25]. Thus, lactic acid is isolated and polymerized to yield a low molecular weight, brittle polymer whose chain length could be increased by using external coupling agents [27].

The last group of biodegradable materials is represented by blends of biopolymers and polymers obtained by chemical synthesis from fossil resources [46-48]. Polymers blending is a technique that allows to modify the properties of a material using a conventional technology at low cost. In this way, biodegradable polyesters such as Poly CaproLactone (PCL), which is obtained by the condensation of 6-hydroxycaproic acid or through the ring opening polymerization of $\varepsilon$-caprolactone [49], could be easily used to improve mechanical properties of natural polymers as starch, conferring them a better water resistance due to its hydrophobicity [50].

Nowadays, although with different percentages, all bioplastics are used in a wide range of sectors: from packaging, catering products, consumer electronics, automotive, agriculture/horticulture, and toys to textile fields. The field of application of a given bioplastic material is clearly dictated by its mechanical properties as well as by its biobased content or its biodegradability. These characteristics are evaluated before bioplastics are promoted on the market.

Moreover, to produce functional materials with biological properties, in the case of bioplastics obtained from fruits and vegetable wastes, a metabolic characterization of the raw material is needed. Among the analytical techniques used to this aim, both chromatography and the mass spectrometry are critical as they allow both targeted and untargeted characterization of the main classes of metabolites occurring in a given matrix [51-62].

\subsection{Bioplastics Bio-Based Content and Biodegradability}

Both bio-based and either biodegradable plastic materials have become the world's most widely choice among bioplastic materials as their production has a low environmental cost compared to traditional plastic ones [63]. To promote the diffusion of either bio-based or biodegradable plastic materials, the Public Procurement Working Group of the European Commission's Expert Group for Bio-based Products published 15 recommendations in order to enable procurement policies to embrace eco-friendly materials. Due to emerging trade of this type of materials, it is necessary to establish a labelling harmonization, as well as the existence of standards and test methods to define and measure properties and characteristics like bio-based content, biodegradability, and other attributes unique to ready-to-market products.

The bio-based content of a material is the amount of the biomass-derived carbon, as compared to its total organic carbon content (TOC). The carbon content of biobased materials is determined independently and unequivocally as reported in international standard methods of the American Society for Testing and Materials (ASTM) and of the International Organization for Standardization (ISO). In detail, ASTM D6866-20 and ISO 16620-2 methods report radiocarbon analysis as the technique to determine the bio-based content of solid, liquid, and gaseous samples. The employment of the radiocarbon dating method is based on the significative difference in ${ }^{14} \mathrm{C}$ isotopic signature between the fossil derived $\left({ }^{14} \mathrm{C}\right.$-free) and the biomass derived $\left({ }^{14} \mathrm{C}\right.$-including) materials. In detail, the presence of ${ }^{14} \mathrm{C}$ in the bio-based materials is due to the fact that ${ }^{14} \mathrm{C}$ containing carbon dioxide formed in the atmosphere, participates in the photosynthetic processes from which 
the biomass derives. Thus, the ${ }^{14} \mathrm{C}$ content of biomass derived materials is the result, in a first approximation, of ${ }^{14} \mathrm{C}$ atmospheric levels $[64,65] .{ }^{14} \mathrm{C}$ measurements could be done by using Accelerator Mass Spectrometry (AMS) along with Isotope Ratio Mass Spectrometry (IRMS) or by using Liquid Scintillation Counting (LSC) techniques (ASTM International, 2020). In order to define a bioplastic as bio-based, a biomass-derived carbon content not less than $25 \%$ is required [66].

Another key bioplastic property to be measured is the biodegradability [26], which refers to the ability of a material to decompose after interactions with biological elements. The biodegradation of polymers involves three steps: bio-deterioration, bio-fragmentation, and assimilation (Figure 2) [67]. Bio-deterioration is the modification of mechanical, chemical, and physical properties of the polymer due to the growth of microorganisms on or inside the surface of the polymers. In the bio-fragmentation step, microorganisms fragment polymers in oligomers and monomers, which, in the next assimilation step, are available as their carbon, energy, and nutrient sources finally with $\mathrm{CO}_{2}$, water, and biomass as by-products [26]. It should be pointed out that only specific microorganisms could degrade a given type of bioplastic. It has been reported that PCL can be degraded by bacteria isolates that exist in deep sea sediments, but these isolates are incapable of degrading other types of bioplastics, such as PLA, PHB, and PBS; however, there exist composting bacteria capable of degrading the latter [26].

Polymers undergo chemical, mechanical, and physical change, as a result of the microorganisms' biological activity on the surface of the material.

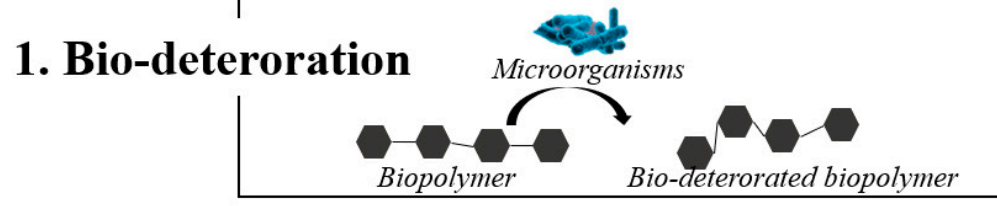

The the microbial activity causes the breaking down of polymers into oligomers and monomers.

2. Bio-fragmentation
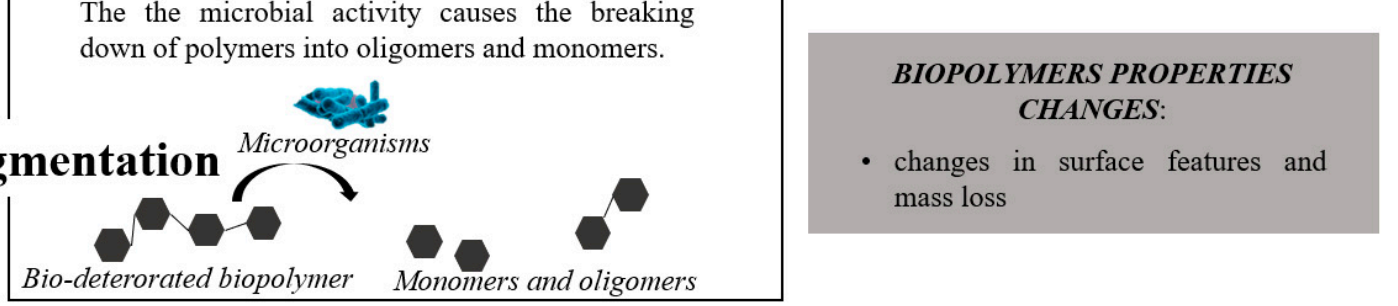

Bio-fragmented compounds are used by the microorganisms and are converted to biodegradation end products, such as $\mathrm{CO}_{2}, \mathrm{H}_{2} \mathrm{O}$ and biomass.

\section{Assimilation}

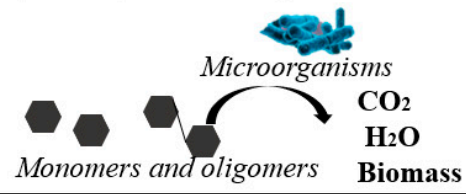

BIOPOLYMERS PROPERTIES CHANGES:

- decrease of mechanical properties
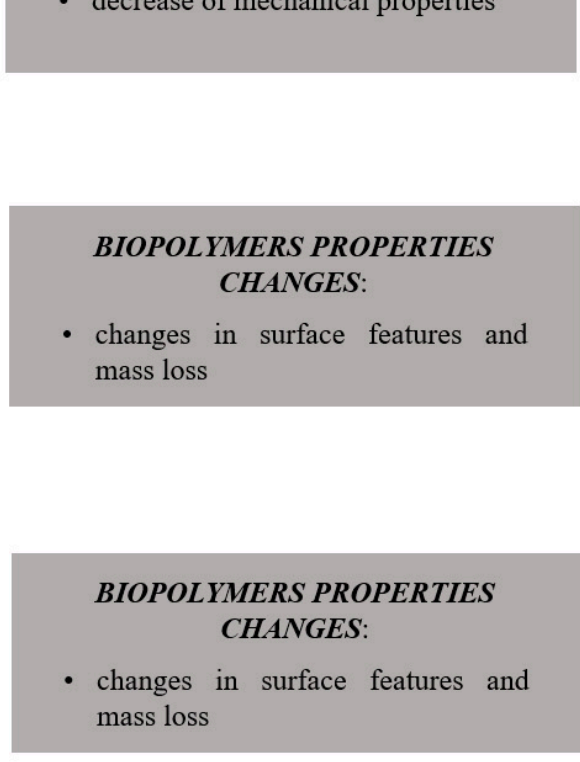

Figure 2. The main three steps through which the biodegradation of polymers occurs: (1) bio-deterioration, (2) biofragmentation, and (3) assimilation.

The biodegradation of bio-plastic materials is highly dependent on their chemical structures. Generally, polymers with a shorter chain, more amorphous parts, and less complex formula are more susceptible to biodegradation by microorganisms [68]. The presence of additives could influence the biodegradability of a matrix. As an example, polypyrrole, the archetype of polymers integrated in biosensing devices for biomedical applications, can acquire enhanced biodegradability if grafted onto cellulose chains, thus forming biocomposite $[69,70]$. Moreover, the $\mathrm{pH}$, temperature, and the oxygen content of 
the environment in which the polymers are placed or disposed of, could be key factors for their biodegradation [71,72]. For example, oxidative-degradable polymers accelerate their decomposition under the effect of oxidation through heat and/or UV light. UV radiation can disrupt polymer chains, since the radiation can be absorbed by oxygencontaining components to initiate a primary degradation; these polymers are known as photodegradable polymers. During photodegradation, both molar mass and crystal structure are affected. The plastics that have the capacity to biodegrade by hydrolytic mechanisms such as biopolymers made of cellulose, starch, and polyesters such as PHA are known ad hydro-biodegradable bioplastics [73].

To date, a wide variety of methods for measuring the biodegradability of polymeric biomaterials have been currently developed and most of them are in agreement with ASTM, ISO, and European Standards (EN) standard methods in terms of environmental conditions, timings, and scales of the tests. Overall, all methods are focused on an indirect measure of degradation process, such as oxygen consumption or biogas generation $\left(\mathrm{CO}_{2}\right)$ by measuring differences of pressure in the test flasks and carbon dioxide production [24]. A biodegradation level higher than $90 \%$ in comparison with cellulose (positive standard) in 180 days, under conditions of controlled composting measured through respirometric methods has been established by the European Norm EN 13,432 as the level for a mate$\mathrm{rial} /$ product to be defined as biodegradable and compostable. In addition, a disintegration level higher than $90 \%$ in three months and the respective ecotoxicity and chemical safety criteria should be kept. Then, only when the products meet the EN 13,432 standard criteria can the wording "biodegradable" be reported on the packaging label.

The biodegradation of bioplastics has beenextensively investigated in soil and compost environments, where they mainly showed high degradability [26]. Anyway, the conditions of the experiments conducted to study the bioplastics biodegradability are highly variable, and to make a clear comparison among them is difficult. The experiments carried out in compost or in anaerobic digestion environments show a biodegradability over $50 \%$ in 65 and $68 \%$, respectively. For those carried out in aquatic environments, this share is $44 \%$, and for experiments carried out in soil, it is $33 \%$ of the cases [73].

It should be pointed out that, in addition to increasing bio-based content and biodegradability, bioplastics intrinsic properties often need to be improved to meet industrial expectations. The optimization can concern, for example, mechanical properties, increased material flexibility, increased rigidity, increased resilience, and improvement of water absorption capacity [74-76].

\subsection{Bioplastics Mechanical and Physical Properties}

In order to assess the suitability of a biomaterial for a given sector and to establish the service life that can be expected, an evaluation of its mechanical-physical properties is mandatory. The main mechanical properties that are typically tested after the production of a bioplastic are the ultimate tensile strength, the Young's Modulus, and the elongation at break. The ultimate tensile strength, or just tensile strength, indicates the maximum stress that a material can withstand before fracturing, while the Young's Modulus, also known as elastic modulus, defines the stiffness of a material: the bigger is its value, the stiffer the material [77]. As regard to the elongation at break values, they are a measure of material ductility and depend on the rate (crosshead speed) and the temperature. The elongation at break value is, generally, very small and close to zero for brittle materials. On the contrary, materials with a better capacity to handle an excessive load without failure show higher elongation than $100 \%$ [78]. Clearly, all these properties are affected by the chemical structure, the orientation degree of the polymers, and the crystallinity of the material, as well as by the eventual presence of fibers that act as reinforcement, or plasticizers [79,80]. Plasticizers are low volatile molecules, added to bio-polymeric materials to ensure an increasing of their extensibility, dispensability, flexibility, and elasticity [81]. Several theories to explain the mechanisms of plasticization action have been proposed [82]. The lubrication theory states that plasticizers, by interspersing themselves, act as internal lubricants by 
reducing frictional forces between polymer chains. The gel theory, instead, postulates that the rigidity of polymers comes from three-dimensional structures, and plasticizers take effect by breaking polymer-polymer interactions (e.g., hydrogen bonds and van der Waals or ionic forces). The free volume theory states a plasticization as a study of ways to increase free volume and is useful in explaining the lowering of the glass transition temperature $\left(T_{\mathrm{g}}\right)$ by a plasticizer. Ideal plasticizers should be miscible and compatible in all proportions with plastic components, and they may be added to polymers in solution (dispersion technique) or after solvents have been removed (absorption technique) [83,84]. Water, oligosaccharides, polyols, and lipids are different types of plasticizers widely used for edible films and coatings [85].

For hydrophilic polymers, polyols have been proven to be very efficient as plasticizers $[86,87]$. In detail, for bio-based polymers obtained from fruits and vegetables waste, the recent researchers have focused on the usage of glycerol [88-92] and sorbitol [93]. Glycerol content has significant effects on the mechanical properties as well as on the dynamic rheological behavior of thermo-molded bioplastics. Indeed, it was demonstrated that the increasing of glycerol content decreases tensile strength and Young's modulus but improves ductility at room temperature [94]. Several studies on plasticization of chitosan films revealed that poly(ethylene glycol) (PEG) could improve the elastic properties of the chitosan biopolymer. Caner et al. [95] observed that chitosan plasticization using PEG was stable until nine weeks of storage (Figure 3).

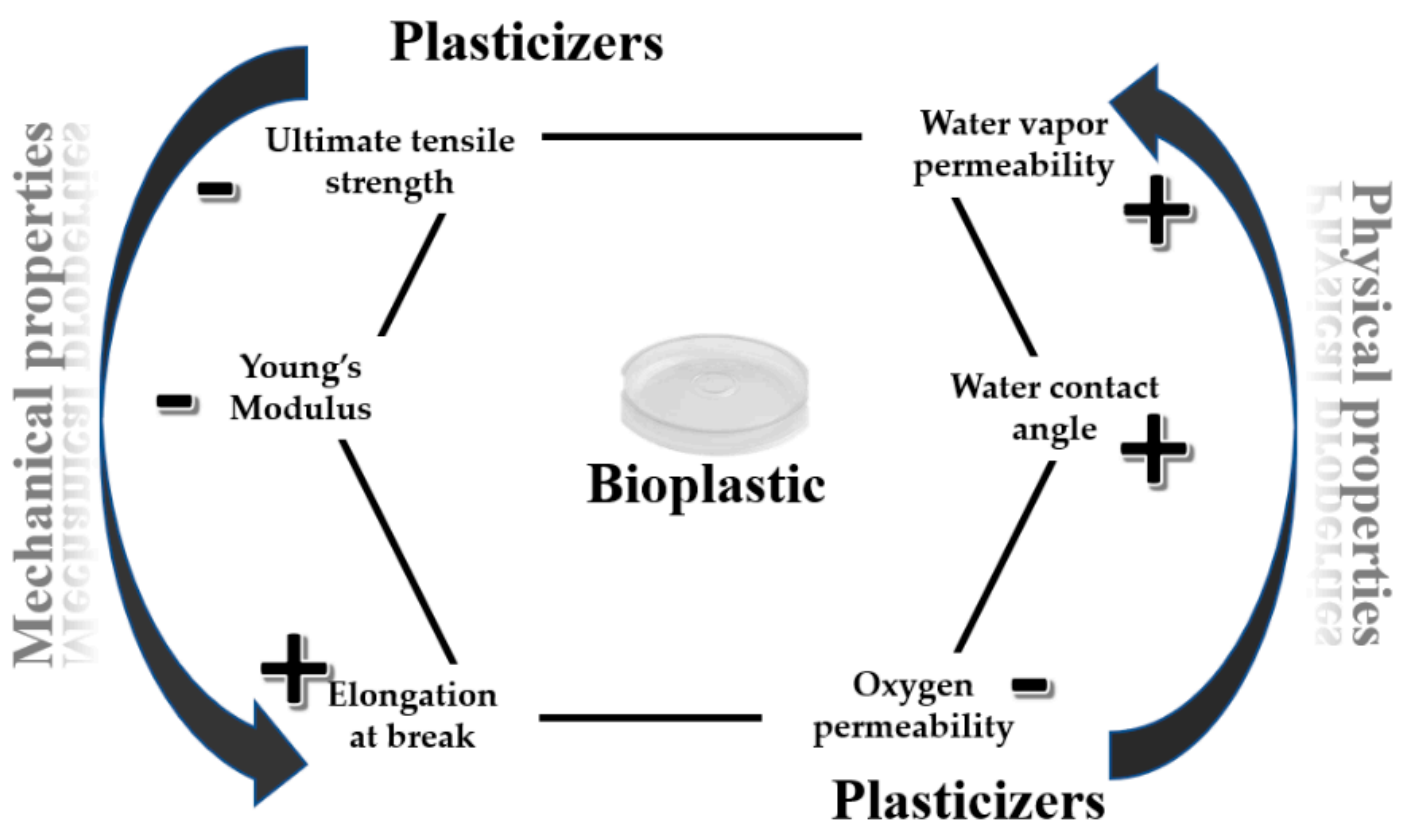

Figure 3. Effects of the plasticizers' addition on mechanical and physical properties of bioplastic materials.

In addition to the mechanical properties, plasticizers also affect the physical properties of the biomaterials, which means water vapor permeability (WVP), oxygen permeability (OP), and water contact angle (WCA) (Figure 3) [46]. These parameters serve as indicators of how easily water vapor or oxygen can penetrate a biodegradable material and they are a function of the hydrophilicity and hydrophobicity ratio of the main components by which the biomaterial is made. As to water contact angle, which is measured as the angle between the baseline of a drop deposited on the surface of the material and the tangent at the drop boundary, it increases with increasing surface hydrophobicity [87]. Since the surfaces degree of hydrophobicity is important to ensure good barrier properties, the evaluation of WVP, OP, and WCA is demanded. Recently, Aguilar et al. [96] found that different physical and mechanical properties could be achieved at room temperature for bioplastics based on a soy protein isolated as a byproduct of the soy oil industry and 
added with different polyols, i.e., s (glycerol (GLY), ethylene glycol (EG), diethylene glycol (DEG) and triethylene glycol (TEG). In this sense, TEG-bioplastics were opaque, brittle, and also had a higher water uptake capacity, while EG-bioplastics were more ductile and translucent, absorbing much less water when immersed. Only GLY and TEG remained in the bioplastic after 9 days of storage at $50^{\circ} \mathrm{C}$, pointing out the volatility of EG and DEG causing a major ageing effect. On the other hand, it was also observed that sugars like sucrose and trehalose could act as plasticizers in presence of water. In detail, when water is included in the bioplastic formulation together with glycerol, sugars are solubilized within the aqueous fraction, and then play a plasticizer role in the bioplastics. In that case, lower viscoelastic properties and greater water absorption ability are generally detected [97].

\section{Food Waste as Feedstock for Bioplastic Production}

The most recent research concerning bioplastic production focuses on by-products and waste materials of food industries. According to the Food and Agriculture Organization (FAO) of the United Nations, every year an estimated 1.3 billion tons of food is wasted globally from all stages of the food supply chain including post-production, handling/storage, manufacturing, wholesale/retail, and consumption. Since food waste landfilling yields undesirable results, such as greenhouse gas (GHG) emissions and groundwater contamination, their valorization through bioplastics production could offer the possibility to overcome their disposal problem by renewable sustainable processes [19]. In addition, the production of value-added products while reducing the volume of waste is expected to reduce the production cost of biodegradable plastics, e.g. compared to conventional routes of production using overpriced pure substrates [19].

Food waste (FW) can be valorized in several ways in order to produce bioplastics (Figure 4).

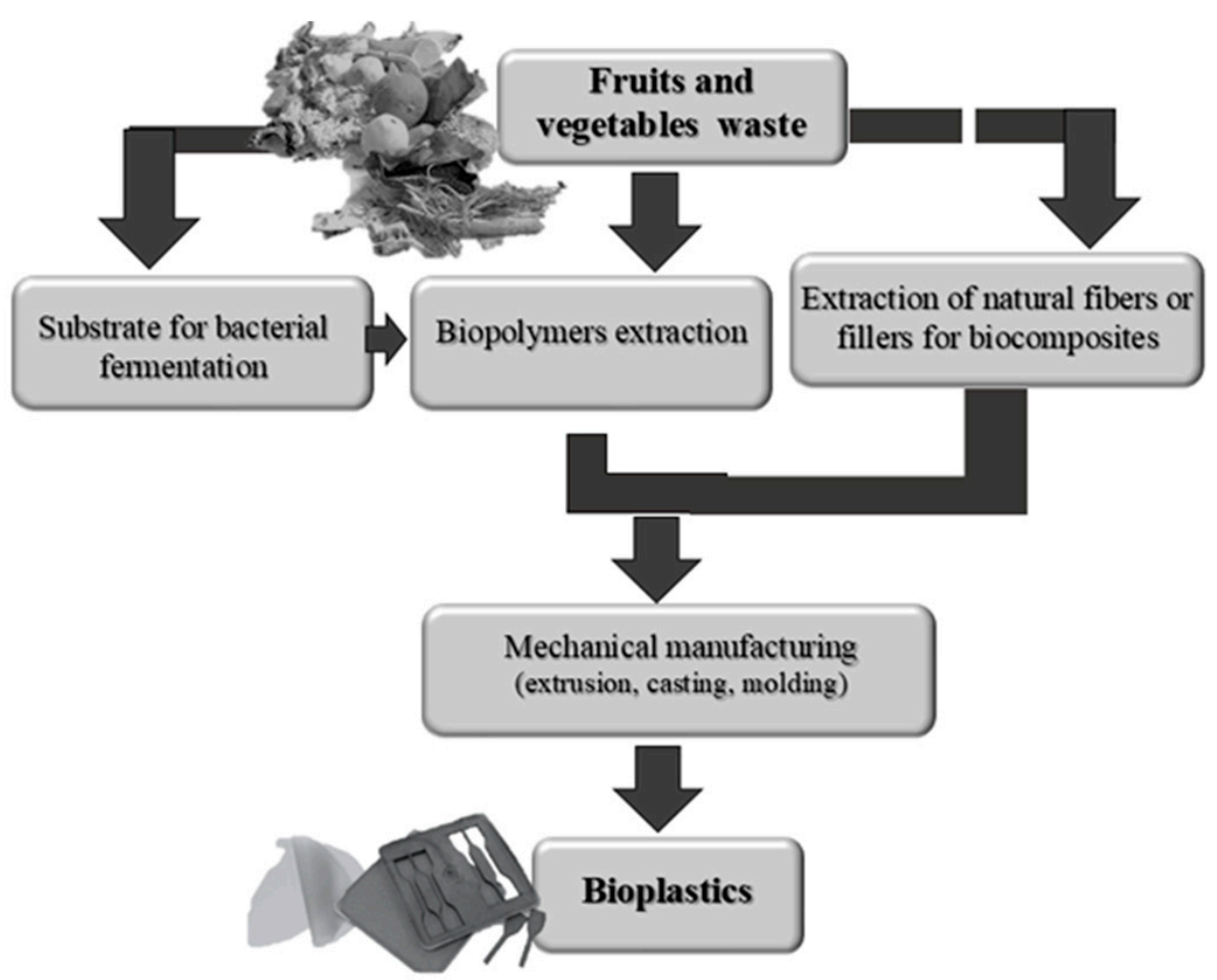

Figure 4. Conversion of food wastes into bioplastics could occur through biopolymers extraction and their mechanical manufacturing (extrusion, casting, molding, or combination of them). In more complex processes, food wastes are used as substrate for bacterial fermentation in order to produce biopolymers or as raw material for the extraction of other natural components, such as fibers, which act as reinforcing agents and/or natural filler of biocomposites. 
It is often used as substrate for bacterial fermentation to obtain natural polyesters, namely PHA and polylactic acid (PLA). When used to produce PHAs, food waste is a prime candidate for an inexpensive carbon source, due to its widespread availability and the potential to solve significant waste problems. In this case, physical, thermochemical, and biological pre-treatments of the FW are requested. Briefly, as reported by Tsang et al. [19], a preliminary liberation of monomers from the FW (e.g., lignocellulosic components) with increasing accessibility of proteins, lipids, and polysaccharides (e.g., starch and cellulose), for subsequent enzymatic hydrolysis and fermentation, are essential. After the pre-treatment, the FW is ready for fermentation step in presence of bacteria, by using several cultivation strategies.

Other simple technologies for the production of bioplastics involve the direct extraction, from the food-waste-stream, of the biopolymeric components that are worked to give the finished products. More complex processes, on the other hand, require additional steps through which the biomass or the biopolymers extracted from it are used as reinforcements or fillers for the realization of biocomposites [98].

In many cases, the different "bioplastic formulations" need to be blended with additives in order to optimize some properties of the materials, such as thermal instability, high water vapor, brittleness, and low melt strength. Plasticizers, like glycerol, for example, are often required to improve the processability and the mechanical properties by interrupting hydrogen bonding and reducing the interactions between the biopolymers chains [81].

However, both formulations, biopolymerics and biocomposites, are lastly processed to obtain biofilms or three-dimensional objects by applying conventional mechanical techniques: extrusion, molding, casting, or a combination of them $[88,99,100]$. All these processing methods selected for the manufacture of food waste-based bioplastics play an important role in their final properties [101]. Extrusion is a highly efficient way for the continuous shaping of biomaterials, and it consists in pushing the bioplastic dough against an orifice with the desired geometry and dimensions. The mass of the dough inside the extrusion chamber is compacted, and the semi-finished product that comes out is cut to give the wanted length. Instead, with casting and molding, the dough is respectively poured or pressed against a rigid frame.

Compression molding technique has been widely employed for the development of biofilms or 3D objects without the use of any solvent or binder [88,102]. With this technique, the waste of interest or its dried extract is finely powdered and subjected to high temperatures and pressures through a heated press. Under this thermo-mechanical treatment, proteins undergo denaturation and dissociation leading to the formation of new links and their aggregation to new forms; in addition, biopolymers show a self-binding ability that is exploited to produce three-dimensional objects. Furthermore, the molding method is more suitable for industrial applications since it is characterized by lower energy demand and processing time compared to other techniques like solution casting [102].

In the last 10 years, several food wastes have been used as raw material for the production of bioplastics, including biocomposites; mostly fruit and vegetable wastes rich in polysaccharides (such as cellulose, starch, pectin) and in fibers [90,93,101,103-105] (Table A1). In the next paragraphs, a focus on the main uses of fruits and vegetables wastes for the production of bioplastics will be provided.

\subsection{Biopolymers-Based Plastics}

Biopolymers extracted from fruits and vegetables wastes show different characteristics and properties that make them more or less suitable for the production of eco-friendly materials (Table 1). The extraction of biopolymers from food waste could be achieved chemically or enzymatically. Enzymatic processes are widely considered "clean" since they are solvent-free [106]; however, this technology is still hindered by economic and technical limits, i.e., costly enzymes and long processing period. Because of the high cost and time-consuming nature, the production of bioplastics through sugar's bacterial fermentation, occurring in agricultural waste, is disadvantageous. Therefore, chemical 
extraction with solvents could be considered as the best solution at the lowest amount of energy.

Table 1. Properties associated with the main biopolymers extracted from fruits and vegetable wastes for bioplastics production.

\begin{tabular}{|c|c|c|c|}
\hline Biopolymer Name & Biopolymer Type & Properties & $\begin{array}{c}\text { Fruits and Vegetable Wastes } \\
\text { Used as } \\
\text { Biopolymer Source }\end{array}$ \\
\hline Cellulose & Polysaccharide & $\begin{array}{l}\text { Highly structured intermolecular } \\
\text { hydrogen bonding network; } \\
\text { impossibility of melting or } \\
\text { dissolution by standard processes } \\
\text { such as thermoforming. }\end{array}$ & $\begin{array}{l}\text { Banana peels, carrots waste, } \\
\text { cauliflower waste, cocoa pod } \\
\text { husks, orange peels, parsley } \\
\text { steams, radicchio waste, rice hulls, } \\
\text { spinach steams, tea leaves waste. }\end{array}$ \\
\hline Starch & Polysaccharide & $\begin{array}{l}\text { Strong inter- and intra-molecular } \\
\text { hydrogen bonding; water } \\
\text { sensitivity and poor fowability; } \\
\text { brittleness. }\end{array}$ & $\begin{array}{l}\text { Banana peels, cassava peels, } \\
\text { potato peels. }\end{array}$ \\
\hline Pectin & Polysaccharide & $\begin{array}{l}\text { Gelling ability but poor tensile } \\
\text { and barrier properties; water } \\
\text { sensitivity. }\end{array}$ & $\begin{array}{l}\text { Apple pomace, banana peels, } \\
\text { citrus waste, orange peels }\end{array}$ \\
\hline Cutin & Polyester of hydroxy fatty acids & $\begin{array}{l}\text { Amorphous and flexible } \\
\text { three-dimensional polymer; } \\
\text { hydrophobic, low water } \\
\text { sensitivity. }\end{array}$ & Tomato waste \\
\hline
\end{tabular}

One of the main macromolecules extracted from fruits and vegetables waste and used for the production of biomaterials is the cellulose. The preparation of the pure cellulose bioplastics from bio-sources is not easy due to the highly structured intermolecular hydrogen bonding network of the polymer, which cannot be melted or dissolved by standard processes such as thermoforming $[37,107]$. Thus, the cellulose is usually used in industrial applications in the form of derivatives, such as esters or ethers, from which cellulose is then regenerated [108]. Nevertheless, in recent years, several biomaterials have been manufactured through amorphous cellulose extracted from vegetables by using different solvents. Bayer et al. [37] obtained amorphous cellulose-based biomaterial by digesting parsley and spinach stems, rice hulls, and cocoa pod husks wastes in trifluroacetic acid (TFA), followed by casting and evaporation. TFA is a naturally occurring and biodegradable organic acid that can co-solubilize cellulose with other contained organic matter; it breaks the hydrogen bonds between neighboring cellulose chains (intersheet hydrogen bonds) and partial trifluoroacetylates $\mathrm{OH}$ groups of cellulose with formation of amorphous materials [109]. The mechanical properties of the produced cellulose-based biofilms were proved to be largely dependent on the starting biowaste. Indeed, cocoa pod husks biofilm displayed a tensile stress at break of approximately $30 \mathrm{MPa}$; whereas for the rice, the parsley, and the spinach-derived films, the obtained values were, respectively, $7 \mathrm{MPa}, 5 \mathrm{MPa}$, and approximately $1 \mathrm{MPa}$, i.e., values close to elastomers and low density polyethylene thermoplastic [37]. Such higher stresses at break and strains for cocoa pod husks derived biomaterial were due to their significant number of triglycerides, i.e.oligomeric esters precursors of biopolymers. Instead, residual silica in the rice hulls derived material conferred a higher rigidity compared to parsley- and spinach-based biomaterials. UTS (ultimate tensile strength) at high Young's modulus comparable to poly(ethylene terephthalate) of bioplastics from cocoa pod husk could be compared with petroleum-based thermoplastics, such as high-density polyethylene and polypropylene. Rice straw was used also by Bilo et al. [110] to produce a new cellulose-based bioplastic material through a process that involved the digestion with TFA, preceded by an extraction pre-treatment performed in a rapid dynamic solid-liquid extractor. With this process, a bio-material with better mechanical properties, 
compared to those evaluated by Bayer et al. [37], was obtained. Indeed, the tensile test of dried and wet dumbbell specimens allowed to ascertain tensile strengths and elongations at break equal to $45 \mathrm{MPa}$ and $6.1 \%$ and $10 \mathrm{MPa}$ and $63 \%$, respectively (Table A1). The replacement of TFA with a diluted aqueous cloridric acid $(\mathrm{HCl})$ solution has been found to be a better method to obtain biofilm evidencing higher stiffness and lower ductility. Perotto et al. [111] used this water-based process to convert carrot, parsley, radicchio, and cauliflower wastes into flexible bioplastic films made by cellulose crystals fused together, with some soluble components like pectin and sugars blended homogeneously acting as plasticizers. Compared to the oil-based polymers, the Young's Modulus (1.3 $\pm 0.2 \mathrm{GPa})$ and the UTS (38 $\pm 5 \mathrm{GPa}$ ) of the carrot bioplastics are similar to those of polypropylene, albeit with lower elongation. The mild conditions of the conversion process were demonstrated also to preserve the functional properties of the original vegetable, like the anti-oxidant activity [111]. An aqueous $\mathrm{HCl}$ solution was used also by Yaradoddi et al. [89] to produce a cellulose-based biofilm from banana peels; anyway, in this case, no mechanical tests were conducted in order to evaluate the strength of the material.

Although TFA and $\mathrm{HCl}$ are efficient acids for vegetable waste derived-cellulose dissolution, their utilization, and waste production remain problematic if considering the principles of green chemistry. Recently, a less harmful acid, i.e., citric acid, has been used by Liu et al. [112] in a green, non-toxic, waste-free method of synthesizing hydrophobic bioplastic films from spent tea leaves. The resultant material exhibited an ultimate tensile strength of $6.16 \mathrm{MPa}$ and an elongation at break of $13.33 \%$, thus it had a lower stiffness compared to oil-derived polymers, such as PP (Table A1). Since citric acid was found to not fully react with the tea waste matrix, the authors hypothesized that unreacted citric acid acted as a hygroscopic plasticizer in the bioplastic films.

In addition to cellulose, starch, i.e., a polymer consisting of a long chain of two glucose units joined together, namely branched polymerized amylopectin and amylose, can be considered as an effective eco-solution for the production of biomaterials, because it is inexpensive and easily available (Table 1). Starch for the production of biofilm have been obtain from different sources, principally potatoes, banana and cassava peels [90,113-118]. Arikan et al. [114] investigated the production of bioplastics from potato peels waste, obtaining satisfactory results in terms of biodegradability (the time requested for the complete biodegradation of the material was 28 days, see Table A1). However, native starch-based films are limited to high water affinity and brittleness, therefore other natural biopolymers are often added as fillers to modify and improve films' properties. As example, Dasumiati et al. [116] and Fathanah et al. [117] improved the mechanical properties of cassava peels derived starch by introducing chitosan as filler. In another work, proteins derived from soybeans waste were mixed with starch and glycerol as plasticizer, since proteins structure consists of stable three-dimensional networks which do not ensure material with enough plasticity [119]. Instead, Sultan et al. [90] developed bioplastic film from a combination of banana peels derived starch and different concentrations of corn starch (1\% up to $5 \%$ ) as co-biopolymer. Based on the results obtained, the film with $4 \%$ of corn starch gave the highest tensile strength $34.72 \mathrm{~N} / \mathrm{m}^{2}$ compared to other samples, while the authors stated that the biofilms with 3\% of corn starch were resistant to water uptake by absorbing water up to $60.65 \%$ (Table A1). However, it should be considered that this value is considerably higher compared to conventional plastics such as PP, whose percentage of water absorption after $24 \mathrm{~h}$ of immersion ranges between 0.01 and 0.03 .

Besides being a starch source, banana peels have been shown also to contain a good percentage of pectins [120]. Pectins are a family of covalently linked galacturonic acid-rich plant cell wall polysaccharides with functions in plant growth, morphology, and development; they also serves as gelling and stabilizing polymers in diverse foods [121]. The production of pectin-based biofilms typically involves the introduction of cellulose and hemicellulose components, since polysaccharidic films show poor tensile and barrier properties compared to those of petroleum-derived polymers. To this regard, Oliveira et al. [75] isolated pectin from banana peels in order to prepare a biofilm whose tensile strength was 
increased through the addition of cellulose nanocrystals (CNCs) extracted from the same banana wastes (tensile strength values obtained were about $7 \mathrm{MPa}$, see Table A1). The tensile strength increase was due to favorable nanocrystal-pectin interactions as well as to the reinforcing effect through stress transfer at the nanocrystal-pectin interface [122].

Aside from the poor mechanical properties, the strong hydrophilic character of polysaccharidic films makes them dissolve in contact with water, limiting their applications [75]. To overcome the high water permeability, citric acid could be added, as it crosslinks polysaccharide films by forming covalent diester linkages between two of their carboxyl groups and hydroxyl groups of different polysaccharide chains [123]. In the previous mentioned work reported by Oliveira et al. [75], the presence of citric acid was ascertained to decrease the water vapor permeability from 3.31 to $3.10 \mathrm{~g} \cdot \mathrm{mm} \cdot \mathrm{kPa}^{-1} \cdot \mathrm{h}^{-1} \cdot \mathrm{m}^{-2}$. Citric acid was used also for the processing of orange and apple wastes (OW and AW) in order to obtain a biodegradable material through a casting method in which cellulose and hemicelluloses were suspended in the pectin solution and further dried to a film [88,92]. In detail, Batori et al. [92] used a solution of citric acid and glycerol to form a biofilm from OW, exploiting the gelling ability of pectin and the strength of its cellulosic fibers. The tensile strengths of the films were $31.67 \pm 4.21$ and $34.76 \pm 2.64 \mathrm{MPa}$, respectively, for the oven-dried and incubator-dried films. These values were within the range of different commodity plastics. In addition, anaerobic digestion was performed for testing the biodegradability of the material and a time of 15 day was requested to reach $90 \%$ of degradation. Instead, from a mixture of apple pomace waste (AW) and glycerol, a fluffier and connected structure (tensile strength $3.27 \pm 0.31 \mathrm{MPa}$ without including a washing step) was obtained by Gustaffson et al. [88], but with significant flexibility, similar to those of PP (elongation \%: $55.41 \pm 5.38$, Table A1).

The same authors [88] made an attempt to produce bioplastics by using solvent-free mechanical processing of AW. Compression molding technique has been widely employed for the development of pectin-based biofilm or 3D objects without the use of any solvent or binder [88,102]. Gurram et al. [102] applied a compression molding method for production of bioplastic films from citrus peel derived pectin. Moreover, free sugars and water-soluble nutrients were extracted from citrus waste and employed for cultivation of the filamentous fungus Rhizopus oryzae, whose biomass was incorporated into the pectin films. The addition of fungal biomass (up to 20\%) enhanced the tensile strength (16.1-19.3 MPa) and reduced the water vapor permeability of the pectin films (Table A1).

In addition to the cellulose, starch, and pectine, a sustainable melt polycondensation of unsaturated and polyhydroxylated fatty acids recovered from tomato pomace agro-wastes, has been recently carried out in order to obtain an aliphatic polyester type of bioplastic without the use of solvents during the reaction [124]. Polyhydroxylated fatty acids are found in tomato pomace in the form of cutin, i.e., a biopolyester mainly composed of $C_{16}$ and $\mathrm{C}_{18}$ fatty acids monomers linked together and forming an amorphous and flexible three-dimensional polymer matrix [125]. Since cutin isolation to produce bioplastics is a long multistep process and unsuitable for large-scale applications, a direct depolymerized of tomato pomace through alkaline hydrolysis, followed by monomers polycondensation, has been proposed by Heredia-Guerrero et al. [124] as a simpler and cheaper alternative. To that purpose, the influence of different temperatures, reaction times, and amounts of tin (II) 2-ethylhexanoate used as a catalyst, was evaluated. Synthesized tomato pomace bioplastics showed an amorphous molecular structure, whose mechanical properties were dependent on the degree of polymerization. In detail, an increase in hardness of the polyesters synthesized at higher reaction temperatures and amount of catalyst was detected ( 1.8 MPa for biopolymers obtained at $125^{\circ} \mathrm{C}$ and $0 \mathrm{mmol}$ of catalyst against $\sim 26.3 \mathrm{MPa}$ for biopolymers obtained at $175^{\circ} \mathrm{C}$ and $0.1 \mathrm{mmol}$ of catalyst), since in those conditions a higher degree of polymerization was achieved. The water-contact angles of more polymerized samples were around $109^{\circ}$, which are values comparable to traditional hydrophobic polymers such as PDMS and PTFE. Concerning water uptakes, the obtained percentages were typical of low-absorbing plastics (2.1-61\%). 


\subsection{Fruits and Vegetables Waste Usage for Biocomposites Production}

More often, biopolymers extracted from fruits and vegetable wastes are blended with other polymers whose mechanical and physical properties are not suitable to accomplish commercially acceptable products [100], thus realizing composite materials known as biocomposites.

Biocomposite materials are usually made by a polymeric matrix coming from a renewable and available origin, such as polysaccharides, reinforced by natural fillers. Examples of natural fillers are layered silicates. They can be synthetized from silica naturally occurring in leaves, husks, blades, hulls, roots, and stems of many terrestrial and marine plants, including wheat, rice, horsetails, oats, barley, grasses, and algae. Among bio-wastes, one of the most silica-rich sources is rice husks, which is largely available, typically 20$22 \mathrm{wt} \%$ of rice grains. It is been used by Deng et al. [126] for layered silicates synthesis. Layered silicates (LSs) have hydrophilic characteristics owing to the presence of inorganic cations $\left(\mathrm{Na}^{+}\right.$and $\left.\mathrm{Ca}^{2+}\right)$ in the interlayer spacing; hence, they are miscible with different hydrophilic polymers, including starch and pectin, able to compensate their rheological property differences [100].

Despite not being recovered from vegetables wastes, Cokaygil et al. [100] used LSs as natural filler to prepare biocomposite films having corn starch and pectin extracted from orange peels as a polymeric matrix. Different pectin jelly-to-starch weight ratios (63/37, $60 / 40,57 / 43$, and $54 / 46 w / w$ ) were considered when formulating the film ingredients. Furthermore, to enhance the compatibility and wettability among starch, LS, and pectin, starch and LSs were chemically modified through reaction with propylene oxide and hexadecyltrimethylammonium chloride, respectively. Among all the films considered, pectin jelly/modified starch-based biocomposite film (54/46 w/w) containing $0.25 \mathrm{wt} \%$ of LSs was found to be the most promising in terms of texture structure and mechanical integrity.

In the most recent years, wastes of agro-food industries have attracted attention also as sources of natural fibers exploitable as reinforcing elements of biodegradable biocomposite materials. Bio fibers, which are natural polymers, could be obtained from a large variety of fruits and vegetables [127], thus reflecting several characteristic properties unlike conventional fibers. Undoubtedly, conventional fibers for instance glass, carbon, and aramid can be produced with a definite range of properties, with a higher cost as well. In 2013, Schettini et al. [105] developed a novel biocomposite by using hemp and tomato peels and seeds fibers as natural reinforcement for sodium alginate polymer, in order to produce biodegradable pots in agriculture. Three different compositions of biocomposites were prepared by varying the percentage of tomato and hemp fibers added to sodium alginate water solution. By soaking the doughs with a calcium chloride solution, a three-dimensional and stable crosslinked network of calcium alginate was obtained as well and it was subjected to investigation of its functionality, physico-chemical and mechanical behavior. As reported by the authors, by increasing the hemp fibers content, a general enhancement of the mechanical parameters of both un-crosslinked and crosslinked samples was registered, since fibers from hemp strands are more rigid, stiff, and long in comparison to the more flexible and short fibers from tomato peels and seeds [128]. Moreover, crosslinked biocomposites showed a lower rigidity and strength with respect to their corresponding un-crosslinked counterparts (Young Modulus for un-crosslinked $100 \%$ tomato fibers biocomposite was $63.62 \mathrm{MPa}$; while for crosslinked $100 \%$ tomato fibers biocomposite Young Modulus was $48.05 \mathrm{MPa}$ ). Such a behavior was due to the loss of adhesive properties, which occurs when carboxylated and hydroxyl groups of alginate are strongly engaged in physical interaction with calcium ions during the crosslinking process, thus reducing the bonding strength between the matrix and the fibers [129]. However, these obtained values were all comparable to those of conventional plastics. Instead, Mathivanan et al. [130] used different percentages of pineapple leaf fibers to reinforce tapioca based bioplastic resin through a method based on extrusion followed by hot compression molding. The 30\% composition showed the best average modulus value 
among other composition, leading to the conclusion that the increase of pineapple leaf fibers increases the modulus strength of the composite.

Since passion fruit waste contains about $60 \%$ of fibers [131] that, when dried, could be used as reinforcement of thermoplastic starch, Moro et al. [132] tried to develop an extruded starchy bioplastic, reinforced with different content of passion fruit peel $(0,4,10$, 16 , and $20 \%$ ), glycerol and starch mix, recovered from corn and cassava. In this way, it was possible to obtain starch-based bioplastic with stronger and midterm elastic property (Tensile strength ranged between 1.6 $\mathrm{MPa}$ and 9.0 MPa, while the elongation at break values were between $24.7 \%$ and $54.5 \%$, see Table A1). Despite this, the tensile strength values were lower of oil-derived polymers.

On the other hand, bio-blend of poly-butylene succinate (PBS) and poly-butyleneadipate-co-terephthalate (PBAT) has been recently proved to be strengthened in terms of higher modulus (3.0 GPa) and lower water absorption $(3.4 \%)$ with the addition of Miscanthus fiber and oat hull followed by reactive extrusion of the dough [133]. Indeed, PBS alone has a tensile strength of around $26.5 \mathrm{MPa}$, elongation of $21.5 \%$, and a modulus of $\sim 48 \mathrm{MPa}$. The incorporation of fiber or cellulose remarkably improves the Young's modulus of neat PBS.

For their rich content in lipids, lignin, and fibrous polysaccharide components (cellulose, hemicellulose), peanut hulls and cocoa shell waste (CW) and hazelnut skin (HS) extracts have also been introduced into synthetic elastomers matrices as reinforcement fillers and plasticizers [76,134,135]. Battegazzore et al. [76] made selective and serial extractions from CW and HS to recover bio-components for producing high-added value PLA and PP plastics. Briefly, a first extraction with diethyl ether mainly separated lipids, phospholipids, and triglycerides, which were worked as plasticizers. In the second extracted fractions, instead, phenolic compounds and flavonoids, such as gallic acid and catechin, were distinguished by UV spectroscopy; therefore, those fractions served as antioxidant and photo-stabilizer for PP. In addition, they positively influenced the PP thermal stability in air; indeed, the temperature of its maximum weight loss was increased from $319^{\circ} \mathrm{C}$ to $330^{\circ} \mathrm{C}$ and $345^{\circ} \mathrm{C}$ by adding HS and CW extracts, respectively. Finally, the last fractions extracted acted as reinforcement filler for PLA and PP; their content linearly influenced the oxygen permeability of the obtained biomaterials (Table A1). Instead, Tran et al. [135] introduced cocoa shell waste powder within an acetoxy-poly(dimethylsiloxane) silicone network through a process that involved a physical mixing with a nontoxic solvent and casting into a mold, with the advantage of direct utilization of CW without any extraction or purification steps. In this case, the antioxidant activity of the final cross-linked bioelastomers was investigated, demonstrating very effective radical scavenging activity against 2,2-diphenyl-1-picrylhydrazyl free radical and 2,2'-azinobis(3-ethylbenzothiazoline6-sulfonic acid) radical cation.

As PLA reinforcement, cellulose extracted from pumpkins peels, and subsequently acetylated, has also been used [136]. In this case, the addition of $10 \%$ of acetylated cellulose enhanced the PLA's mechanical properties with an increase of the storage modulus at $40{ }^{\circ} \mathrm{C}$ of around $40 \%$. More generally, cellulose or cellulose nanocrystals have been obtained from various vegetable or fruit waste, such as banana peels, pine flowers waste, rice straw, palm empty fruit bunch, sago waste, mangosteen peels, and also successfully employed as reinforcements of biopolymers, mainly starch [103,137-141]. In addition, banana pseudostems waste has been recently used to isolate nanocellulose employed for the production of green composites enriched with nano-fillers, such as graphene oxide and nanoclay, and glycerol as plasticizer [91]. As regard to rice straw, besides being considered as reinforcement, its fibers were proved to act as flame-retardant fillers in combination with PLA and lignin by Dahy et al. [142]. Typically, flame retardant used to reduce combustibility of the polymers, are halogen-based additives that act in the vapor phase by a radical mechanism to interrupt the exothermic processes, interfering with the combustion process during heating, pyrolysis, ignition, or flame spread. Instead, a more environmentally friendly alternative that contemplates the incorporation of natural 
fillers, like rice straw derived fibers, mainly acts to dilute the polymer and reduce the concentration of decomposition gases [143].

\section{Environmental Impacts of Agro-Food Waste Based Bioplastics Production}

Nowadays, fruit and vegetable valorization is one of the main pillars of the circular economy; their use to substitute fossil resources for the production of plastics, is a widely accepted strategy towards sustainable development. In fact, the displacing of conventional plastics with food waste-based bioplastics can lead to considerable energy and GHGs emissions savings [19]. However, it should be noted that this is not always true. Further details about advantages and drawbacks related to the bioplastics use and production are given in Table 2. Despite being promoted as a safer alternative to their oil-based counterparts, bioplastics production involves major drawbacks. Indeed, bioplastics are generally not cost-competitive compared to conventional plastics and their production is plagued by low yields and being expensive. Moreover, some bioplastics have a shorter lifetime than oil-based plastics due to weaker mechanical and physical properties, such as greater water vapor permeability than standard plastic, being easy to tear like tissue paper, or being very brittle. Being compostable and biodegradable sounds great, but many bioplastics must follow a specific disposal procedure and require industrial composting in order to avoid being incinerated or going to landfill. On the other hand, biodegradable polymers require a controlled fate to kickstart the expected biodegradation process and as a result, it is nearly impossible to control and ensure the complete degradation of even potentially degradable plastic materials. Subsequently, when they are disposed of in an uncontrolled fashion, they will accumulate in the environment and fragment into microplastics (MPs). These MPs have proven to display diverse impacts over ingested organisms and ecosystem similar to those of conventional MPs, thus bioplastics could be a solution to MPs only if properly disposed of [144].

Table 2. Main advantages and drawbacks related to the production and the use of bioplastic materials.

\begin{tabular}{cll}
\hline Production & $\begin{array}{l}\text { Advantages } \\
\text { Reduction of greenhouse gas emission; saving } \\
\text { fossil fuels, possibility of using a local resource, } \\
\text { less energy during the manufacturing cycle. }\end{array}$ & $\begin{array}{l}\text { Use of croplands to produce items, not } \\
\text { cost-competitive compared to conventional plastics }\end{array}$ \\
\hline Use & $\begin{array}{l}\text { No toxic, no release of chemicals into food if used } \\
\text { as packaging }\end{array}$ & $\begin{array}{l}\text { Often characterized by thermal instability, } \\
\text { brittleness, low melt strength, high water vapor and } \\
\text { oxygen permeability; when hydrophilic polymers } \\
\text { are used, they possess low water vapor barrier and } \\
\text { vulnerability to degradation. }\end{array}$ \\
\hline Disposal & $\begin{array}{l}\text { Biodegradable; broken down by naturally } \\
\text { occurring bacteria; do not persist for many years in ind } \\
\text { the environment. }\end{array}$ & $\begin{array}{l}\text { Controlled fate in order to kickstart the expected } \\
\text { biodegradation process; a specific disposal } \\
\text { procedure must be followed to avoid they fragment } \\
\text { into microplastics which accumulate in the } \\
\text { environment. }\end{array}$ \\
\hline
\end{tabular}

As a matter of fact, the employment of fruits and vegetables waste as reinforcement of non-biodegradable polymers in drop-ins significantly increases the energy demand and $\mathrm{CO}_{2}$ emission compared to biodegradable bioplastics [145].

Therefore, when the aim is the production of new bioplastic materials from agro-food waste, the effective sustainability of the process should be evaluated. The sustainability of bio-based plastics production depends on several factors that are often summarized in the life cycle assessments (LCAs) of the products [146]. Among them, there are availability of commercially viable quantities of renewable feedstock and agricultural waste, scalable and green production routes, cost and competition with synthetic polymers, and useful life and biodegradation/end of life treatment [21]. Many of these aspects are very often not 
sufficiently deepened, thus making it difficult to assess environmental impacts associated with the agro-food waste-based bioplastics production.

The greenhouse gas emissions generated by food waste globally represent the third largest emitter in the world, thus any measure to reduce food waste, even to a small extent, may have a significant impact on overall environmental footprint [147]. However, even though the number of fruits and vegetable wasted every year are estimated to be around 484 million, the volume of waste produced does not predict the availability of agricultural waste for conversion into biomaterials. Indeed, a large quantity is employed in other competing applications such as bio-fertilizer and biogas production [148]. In addition, not all the routes proposed for obtaining bio-materials are applicable on a large scale, since sometimes they require extensive and advanced processing. This mainly concerns biocomposites production, which is often based on obtaining fillers and reinforcements, such as cellulose nanocrystals, through complex treatment of the agro-waste [103,122]. On the contrary, more feasible and scalable processes allow bioplastics production after chemical extraction of agro-polymers from the food waste stream. A low environmental impact is associated with this step, as no harsh chemicals, like pyridine and diethyl ether, are used for the production of PHA, and potential occupational hazards are covered.

Regarding the end of life of the agro-food waste = based bioplastics, reuse and recycling are preferred solutions to energy recovery or disposal. However, to date, for materials other than bio-PE or bio-PET, there is no recycling stream established yet [23]. An alternative is their composting, i.e., their aerobic biodegradation under controlled conditions of temperature, humidity, and aeration [72]. Compostability is a clear benefit of agro waste-based bioplastics compared to conventional plastics, resulting in the creation of more valuable compost.

\section{Bioplastics Market}

Currently, the number of bioplastics produced annually in all the world represents only about one percent of the 360 million tons of plastic materials produced globally. However, due to the growing sensitivity towards the adoption of a "green and circular economy" dependent policy, the global bioplastics production capacity is set to increase from around 2.11 million tons in 2019 to approximately 2.43 million tons in 2024 [23].

With a view to regional capacity development, Asia remains a major production hub with over 50 percent of bioplastics currently being produced there. Presently, only one-fifth of the production capacity is located in Europe. This share is predicted to grow to up to 27 percent by 2023. The expected growth will be supported by recently adopted policies in several European Member States, such as Italy and France.

Innovative biopolymers, such as bio-based PP, bio-based PET, bio-based PA, and PHAs continue to drive the growth in bioplastic production. To date, they make up for 40 percent ( 0.8 million tons) of the global bioplastics production capacities. Bioplastics materials are currently used in an increasing number of markets: From packaging, catering products, consumer electronics, automotive, agriculture/horticulture, and toys to textiles. Among these several market segments, electronics is the less developed (only about $2 \%$ of the global bioplastic production concerns this segment), while packaging remains the largest field of application for bioplastics since around $54 \%$ of the global bioplastic production is used to serve the packaging industry, including shopping bags producers, plastic bottles producers, and food packaging industry [23].

Biodegradable shopping bags are made of polymers that degrade, or decompose, when exposed to air, water, or sunlight. There are three main types of biodegradable bags, i.e., (1) biodegradable bags made from resins containing starches, polyethylene, and heavy metals such as cadmium, lead, and beryllium, (2) biodegradable bags made by using starches combined with biodegradable polymers such as PLA, and (3) oxo-biodegradable bags, which use Totally Degradable Plastics Additives (TDPAt) to stimulate the breakdown of polymers and thus speed up the biodegradation process of conventional plastics. 
As regard to food packaging, in the USA premarketing approval by the Food and Drug Administration is required to ensure that materials are wholesome, safe, and effective [149]. On the other hand, in Europe, food contact materials regulations sets specific manufacturing goals to assure a good quality control system and specifies the thresholds according to the form and composition of polymers, which shall explicitly be authorized in order to preserve food safety (European Commission, 2006; European Commission 2011). Anyway, biobased materials are mostly used to pack short shelf-life products or long shelf-life ones, which do not need very high oxygen and/or water barrier properties, such as fresh fruits, vegetables, pasta, and chips [150]. Actually, biomaterials available show such a wide range of properties, that they are also applicable as packaging materials for other food products, which request stricter conditions, like Modified Atmosphere Packaging (MAP).

Bioplastic materials also offer several advantages in the agriculture sector. Eight percent of the global production of bioplastics is covered by the agriculture and horticulture segment. Examples of bio-based products used in agriculture are mulching films and pots $[105,151]$. Soil mulching is a practice used in cultivation, which allows weed suppression, reduces the loss of moisture from the soil, and may promote the increasing of soil temperature. Ploughing-in of bio-based and biodegradable mulching films after use instead of collecting them from the field and cleaning off the soil is a more practical and time saving solution. In the same way, bio-based pots are used.

For the automotive field, instead, components made completely or partially from bioplastics can provide a safety standard, that is of ultimate importance in the transportation sector. The products include seat and airbag covers as well as steering wheels. Some of the bio-based plastics such as bio-based polyamides and bio-based polyesters are already successfully being used by leading automotive brands around the world today with the aim of reducing their products' environmental impact. For example, Toyota typically uses bio-based polypropylene/polylactic acid (PP/PLA) composite derived from plant materials for the realization of up to $60 \%$ of the interior design of cars.

Biopolymers find applications in several housewares, such as kitchen tools and utensils, washable storage containers and cups, bathroom accessories, toys, hangers, and hooks. For example, hangers from United Colors of Benetton are made of biodegradable polymers. Nontoxic biodegradable polymers are also being used as sutures by surgeons in life-saving heart operations and other procedures. Easily sterilized, the sutures remain strong and intact until the surrounding tissues have healed. The sutures dissolve and are readily metabolized in the body leaving no trace. Moreover, there has been a surge of bioplastic products that are being introduced in the fast-moving consumer electronics sector, such as touch screen computer casings, loudspeakers, keyboard elements, mobile casings, vacuum cleaners, and a mouse for a laptop. SUPLA produced the first bioplastic touch screen computer by using PLA, in collaboration with a Taiwanese company (Kuender).

To date, a lot of companies have been identified as key players in the production of bioplastics and their distribution witnesses that the majority of them are located in Europe. Many of these companies produce sustainable bioplastics made from plant-based renewable resources, like corn, potatoes, and wheat. The land used to grow the renewable feedstock for the production of bioplastics is estimated to be 0.7 million hectares in 2021 and continues to account for 0.015 percent of the global agricultural area of 4.7 billion hectares. Despite the market growth predicted in the next five years, the land use share for bioplastics will only slightly increase to 0.02 percent.

Novamont SpA (www.novamont.com) is one of the major starch bioplastics producers. The trade name of their starch-based bioplastic is "Mater-Bi" and it is provided for a wide range of manufacturers, which use it to make bags, mulching film, disposable tableware, and packaging. Furthermore, Amynova Polymers GmbH (www.amynova.com) is engaged in the production of a starch-based substance named "CropCover". CropCover is an innovative "adhesive" non-toxic, non-combustible, and fully biodegradable applied together with pesticides and foliar fertilizers, in order to reduce their rinsing during heavy rainfall and to guarantee a longer stay time on the plant. Biotec Biologische Naturverpackungen 
GmbH \& Co. KG (www.biotec.de) and Cardia Bioplastics (www.cardiabioplastics.com) produce and sell a new generation of customized thermoplastic materials too, with various functional properties fully biodegradable and compostable according to EN 13432. Moreover, there are companies that exploit waste as feedstock for bioplastics production; an example is NaturePlast (www.natureplast.eu). Since 2015, NaturePlast has been producing and marketing a range of biocomposites consisting of by-products and plant fibers (such as hemp), sourced mostly from the French territory. The objective is to incorporate by-products or local waste materials in different polymers to ensure a circular economy and the reclamation of waste materials.

\section{Conclusions}

The valorization of food waste (FW) can create opportunities to produce new valuable bioplastics, which represent an eco-friendly alternative to conventional petroleum-based plastics. Bioplastics produced from fruits and vegetables waste are compatible with the "circular economy", therefore with "zero waste" or more precisely aiming at a complete use of it; moreover, they could create positive synergies between industry and the agro-food sector, with considerable advantages for environmental pollution. This review highlights that the real challenge is to create new eco-friendly materials from food waste and not from specially grown crops, whose production comes at an environmental cost. As the FW potential as raw material for bioplastics production is well known, such a novel perspective focusing on the overall methods used for the design of biomaterials starting from both fruits and vegetables wastes, provided in this review, should be particularly helpful in the fields of the green chemistry and of the environmental sciences.

Author Contributions: Conceptualization, M.A.A.; investigation, M.A.A.; writing-original draft preparation, M.A.A.; review and editing, R.P.; supervision, G.M., M.B., and G.B. All authors have read and agreed to the published version of the manuscript.

Funding: This research received no external funding.

Informed Consent Statement: Not applicable.

Data Availability Statement: Data sharing not applicable.

Conflicts of Interest: The authors declare no conflict of interest. 


\section{Appendix A}

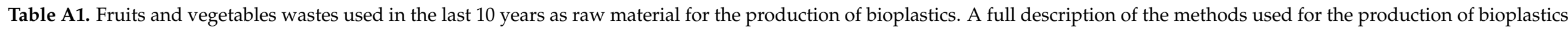
(Technology and pre-treatment of the waste, processing), as well as the main physical and mechanical properties of the obtained materials are provided.

\begin{tabular}{|c|c|c|c|c|c|}
\hline Food Waste Source & Technology and Pre-Treatment & Processing & Bioplastic Type & $\begin{array}{l}\text { Bioplastic Mechanical and } \\
\text { Physical Properties }\end{array}$ & Reference \\
\hline \multirow[t]{2}{*}{ Apple pomace } & $\begin{array}{l}\text { Apple pomace, either washed with water or not, was } \\
\text { powdered. A mixture was prepared containing } 2 \%(w / v) \text { of } \\
\text { powder and } 7 \% \text { glycerol }(w / w \text { of apple pomace powder) } \\
\text { and dissolved in } 1 \%(w / v) \text { of citric acid solution under } \\
\text { heating }\left(70{ }^{\circ} \mathrm{C}\right) \text { and constant magnetic stirring at } 560 \mathrm{rpm} \text {. } \\
\text { Then, the mixture was poured onto a non-sticky plate for } \\
\text { casting. A mixture without glycerol was also used in order } \\
\text { to prepare a biofilm. }\end{array}$ & Casting & Pectin based biofilm & $\begin{array}{l}\text { Tensile strength }(\mathrm{MPa}) \text { : } \\
3.27-16.49 \\
\text { Elongation at break: } \\
10.77-55.41 \%\end{array}$ & Gustaffson et al. [88] \\
\hline & $\begin{array}{l}\text { Apple pomace, either washed with water or not, was } \\
\text { powdered. A mixture was prepared containing glycerol } \\
\text { and apple pomace powder ( } 70: 30) \text { was prepared. } 40 \mathrm{~g} \text { of } \\
\text { the mixture was placed into a mold. A pressure of } 8 \mathrm{MPa} \\
\text { was applied for } 20 \mathrm{~min} \text { at } 100^{\circ} \mathrm{C} \text {. }\end{array}$ & Molding & $\begin{array}{l}\text { Pectin based 3D } \\
\text { biomaterial }\end{array}$ & $\begin{array}{l}\text { Tensile strength (MPa): } 3.02-5.79 \\
\text { Young's Modulus (MPa): } \\
\text { 367.1-633.4 } \\
\text { Elongation at break: } 0.93-1.56 \%\end{array}$ & Gustaffson et al. [88] \\
\hline \multirow[b]{2}{*}{$\begin{array}{c}\text { Banana peels and } \\
\text { pseudostems }\end{array}$} & $\begin{array}{l}\text { Banana peels were boiled in water for about } 30 \mathrm{~min} \text {; then, } \\
\text { they were left to dry and squashed to obtain a paste. } 25 \mathrm{~g} \text { of } \\
\text { banana paste were placed in a beaker with } 3 \mathrm{~mL} \text { of } \mathrm{HCl} \\
(0.1 \mathrm{~N}) \text { and } 2 \mathrm{~mL} \text { of glycerol and stirred. Subsequently, } \\
\mathrm{NaOH}(0.1 \mathrm{~N}) \text { was added in order to neutralize the pH up } \\
\text { to } 7 \text {. }\end{array}$ & Casting & $\begin{array}{l}\text { Cellulose based } \\
\text { biofilm }\end{array}$ & $\begin{array}{l}\text { Weight loss after } 13 \text { days: } 0.04 \mathrm{~g} \\
\text { Difference of weight after } \\
\text { swelling test }(\mathrm{g}): 0.01-0.10\end{array}$ & Yaradoddi et al. [89] \\
\hline & $\begin{array}{l}\text { Banana peels were washed, sliced, and blended. Then, they } \\
\text { were grounded and ground sample was heated at } 150{ }^{\circ} \mathrm{C} \\
\text { for } 2 \mathrm{~h} \text { at } 30 \text { psi. The obtained paste was hydrolyzed } \\
(100 \mathrm{~mL} / 50 \mathrm{~g} \text { sample) by }(\mathrm{HCl}, 99 \%) \text {. The sample was } \\
\text { filtrated and washed with water. } 1000 \mathrm{~g} \text { of sample were } \\
\text { mixed with chlorinated paraffin liquid plasticizers ( } 1: 8 \text { of } \\
\text { sample), } 5 \% \text { acetic acid ( } 5 \mathrm{~mL} / 100 \mathrm{~g} \text { sample), } 5 \mathrm{~mL} / 100 \mathrm{~g} \\
\text { of polyvinylchloride, cellulose }(25 \%) \text { and } 25 \% \text { starch } \\
\text { powder, } 5 \% \text { toluene Phthalates ester and } 10 \% \text { water. Then, } \\
10 \mathrm{~mL} / 100 \mathrm{~g} \text { of PVC and glycerine were added. The } \\
\text { mixture was heated at } 150^{\circ} \mathrm{C} \text { in the oven for } 30 \text { min at } \\
30 \text { psi pressure. }\end{array}$ & Casting & Biocomposite & $\begin{array}{l}\text { Tensile strength }\left(\mathrm{MPa} / \mathrm{kg} \cdot \mathrm{m}^{3}\right) \text { : } \\
120.0 \\
\text { Tensile modulus }(\mathrm{GPa}): 1.1 \\
\text { Water absorption: } 0.03 \%\end{array}$ & $\begin{array}{l}\text { Sharif Hossain et al. } \\
\text { [139] }\end{array}$ \\
\hline
\end{tabular}


Table A1. Cont.

\begin{tabular}{|c|c|c|c|c|c|}
\hline Food Waste Source & Technology and Pre-Treatment & Processing & Bioplastic Type & $\begin{array}{c}\text { Bioplastic Mechanical and } \\
\text { Physical Properties }\end{array}$ & Reference \\
\hline & $\begin{array}{l}\text { Banana peels were immersed in a } \mathrm{Na}_{2} \mathrm{~S}_{2} \mathrm{O}_{5} \text { solution }(1 \% \\
w / v) \text { for } 24 \mathrm{~h} \text {, oven-dried at } 60^{\circ} \mathrm{C} \text { and milled. } 100 \mathrm{~g} \text { of } \\
\text { milled peels were washed three times with ethanol, then } \\
\text { washed in } 200 \mathrm{~mL} \text { of acetone. The pectin was extracted } \\
\text { with a citric acid solution at } \mathrm{pH} 2.0 \text { at } 87^{\circ} \mathrm{C} \text { for } 160 \text { min and } \\
\text { then centrifuged. The supernatant } \mathrm{pH} \text { was adjusted to } \\
3.5 \text { with } \mathrm{KOH} \text {, added with ethanol, stirred for } 30 \text { min and } \\
\text { left to precipitate at } 4{ }^{\circ} \mathrm{C} \text {. The pellet was washed with } \\
\text { ethanol } 70 \% \text {, and dried at room temperature. Then, it was } \\
\text { stirred and its pH adjusted to } 7 \text {, and it was again dried and } \\
\text { milled. For the extraction of cellulose nanocrystals (CNCs), } \\
\text { the alcohol insoluble residue of banana peels was } \\
\text { suspended in a mixture of } 93 \text { wt } \% \text { acetic acid and } 0.3 \text { wt } \% \\
\mathrm{HCl} \text { in distilled water. Subsequently, the pulp was rinsed } \\
\text { and washed in more steps and an acid hydrolysis was } \\
\text { conducted with a } 30 \mathrm{v} \% \mathrm{H}_{2} \mathrm{SO} \mathrm{O}_{4} \text { solution at } 45^{\circ} \mathrm{C} \text {, for } \\
150 \text { min. After centrifugation-dilution-sonication cycles, the } \\
\mathrm{CNC} \text { suspension was dialyzed against deionized water. } \\
\mathrm{CNCs} \text { (at different wt } \%), 4.5 \mathrm{~g} \text { of pectin, } 1.35 \mathrm{~g} \text { glycerol, } \\
\text { citric acid, and distilled water were mixed to form biofilms. }\end{array}$ & Casting & Pectin based biofilm & $\begin{array}{l}\text { Tensile strength }(\mathrm{MPa}) \text { without } \\
\text { citric acid: } 7.36 \pm 1.15 \\
\text { Tensile strength }(\mathrm{MPa}) \text { with citric } \\
\text { acid: } 7.92 \pm 1.21 \\
\text { Elongation at break }(\%) \text { without } \\
\text { citric acid: } 4.69 \pm 0.84 \\
\text { Elongation at break }(\%) \text { with citric } \\
\text { acid: } 4.26 \pm 0.77 \\
\text { Elastic modulus }(\mathrm{MPa}) \text { without } \\
\text { citric acid: } 1586 \pm 487 \\
\text { Elastic modulus }(\mathrm{MPa}) \text { with citric } \\
\text { acid: } 1714 \pm 452 \\
\text { Water vapor } \\
\text { permeability }\left(\mathrm{g} \cdot \mathrm{mm} \cdot \mathrm{kPa}{ }^{-1} \cdot \mathrm{h}^{-1} \cdot \mathrm{m}^{-}\right. \\
\text {without citric acid: } 3.31 \pm 0.36 \\
\text { Water vapor } \\
\text { permeability }\left(\mathrm{g} \cdot \mathrm{mm} \cdot \mathrm{kPa}{ }^{-1} \cdot \mathrm{h}^{-1} \cdot \mathrm{m}^{-}\right. \\
\text {with citric acid: } 3.10 \pm 0.33\end{array}$ & Oliveira et al. [75] \\
\hline & $\begin{array}{l}300 \mathrm{~g} \text { of banana peels were dipped in acetic acid solution } \\
\text { and then placed into a beaker containing } 800 \mathrm{~mL} \text { water and } \\
\text { boiled for } 30 \mathrm{~min} \text {. The water was decanted off and the } \\
\text { peels were left to dry. The banana peels were pureed. To } \\
25 \mathrm{~mL} \text { of the paste, } 3 \mathrm{~mL} \text { of } 0.5 \mathrm{M} \mathrm{HCl} \text { and } 2 \mathrm{~mL} \text { of } 15 \% \\
\text { glycerol solution were added. The mixture was stirred, } \\
3 \mathrm{~mL} \text { of } 1 \% \text { corn starch and } 3 \mathrm{~mL} \text { of } 0.5 \mathrm{M} \mathrm{NaOH} \text { were } \\
\text { added to the mixture and stirred again. }\end{array}$ & Casting & Starch based biofilm & $\begin{array}{l}\text { Tensile strength }\left(\mathrm{N} / \mathrm{m}^{2}\right) \text { : } \\
12.22-34.72 \\
\text { Water uptake: } 60.65-108.98 \%\end{array}$ & Sultan et al. [90] \\
\hline
\end{tabular}


Table A1. Cont.

\begin{tabular}{|c|c|c|c|c|c|}
\hline Food Waste Source & Technology and Pre-Treatment & Processing & Bioplastic Type & $\begin{array}{c}\text { Bioplastic Mechanical and } \\
\text { Physical Properties }\end{array}$ & Reference \\
\hline & $\begin{array}{l}\text { Banana pseudostem was sliced, dryer at } 50{ }^{\circ} \mathrm{C} \text { for } 5 \mathrm{~h} \text { and } \\
\text { milled. Then, } 10 \mathrm{~g} \text { of pseudo-stem flour were soaked in } \\
300 \mathrm{~mL} \text { of } 5 \% \mathrm{KOH} \text {, centrifuged and bleached with } 200 \mathrm{~mL} \\
\text { of } 1 \% \mathrm{NaClO} \mathrm{C}_{2} \text { at pH } 5 \text { for } 1 \mathrm{~h} \text { in } 70{ }^{\circ} \mathrm{C} .9 \mathrm{~g} \text { of the bleached } \\
\text { pseudo-stem were mixed with TEMPO solution and } \\
22.5 \mathrm{~mL} \text { of } 12 \% \mathrm{NaClO} \text {. At the end of the reaction, the } \\
\text { mixture was homogenized and sonicated. Water containing } \\
0.7 \% \text { solid nanocellulose was mixed with glycerol, } \\
\text { nano-clay or graphene oxide in different proportions. }\end{array}$ & Casting & Biocomposite & $\begin{array}{l}\text { Tensile strength }(\mathrm{MPa}): \sim 5-\sim 39 \\
\text { Elongation at break }(\%): \sim 1-\sim 9 \\
\text { Oxygen permeability } \\
\left(\mathrm{mL} / \mathrm{m}^{2 *} \text { day }{ }^{*} \mathrm{~Pa}\right): \\
2 \times 10^{-6}-3.5 \times 10^{-6} \\
\text { Water vapor permeability } \\
\left(\mathrm{g} / \mathrm{m}^{2 *} \text { day }{ }^{*} \mathrm{~Pa}\right): \sim 0.007-\sim 0.023 \\
\text { Contact angle at } 20 \mathrm{~s}\left(^{\circ}\right): \\
21.89-75.03\end{array}$ & Faradilla et al. [91] \\
\hline & $\begin{array}{l}\text { Banana peels were boiled for } 60 \mathrm{~min} \text { and then left to dry } \\
\text { and blended. In order to obtain a chemical-based material, } \\
100 \mathrm{~g} \text { of banana paste were mixed with } 12 \mathrm{~mL} \text { of } \mathrm{HCl}, 8 \mathrm{~mL} \\
\text { of glycerol and } 12 \mathrm{~mL} \text { of } \mathrm{NaOH} \text {. The mixture was stirred } \\
\text { for } 5 \mathrm{~min} \text {. } \\
\text { Alternatively, a natural-based material was obtained by } \\
\text { mixing } 40 \mathrm{~g} \text { of banana peels paste with, } 1 \mathrm{~g} \text { of sage, } 12 \mathrm{~g} \text { of } \\
\text { glycerol, } 12 \mathrm{~g} \text { of potato starch, } 12 \mathrm{~g} \text { of corn starch and } 38 \mathrm{~g} \\
\text { of water. The mixture was dried using the oven at a } \\
\text { temperature of } 120^{\circ} \mathrm{C} \text { for } 3-4 \mathrm{~h} \text {. }\end{array}$ & Casting & Biocomposite & $\begin{array}{l}\text { Tensile strength for } \\
\text { chemical-based material (KPa): } \\
228 \\
\text { Tensile strength for natural-based } \\
\text { material }(\mathrm{KPa}): 150 \\
\text { Young's Modulus for } \\
\text { chemical-based material }(\mathrm{MPa}) \text { : } \\
1.53 \\
\text { Young's Modulus for } \\
\text { natural-based material }(\mathrm{MPa}): \\
1.88 \\
\text { Elongation at break for } \\
\text { chemical-based material: } 18.77 \% \\
\text { Elongation at break for } \\
\text { natural-based material: } 13.97 \%\end{array}$ & Azieyanti et al. [138] \\
\hline & $\begin{array}{l}\text { Banana peels were boiled in water for about } 30 \mathrm{~min} \text {. Water } \\
\text { was decanted and the peels were left to dry and then they } \\
\text { were squashed to obtain a uniform paste. } 25 \mathrm{~g} \text { of banana } \\
\text { paste were mixed with } 3 \mathrm{~mL} \text { of }(0.1 \mathrm{~N}) \mathrm{HCl}, 2 \mathrm{~mL} \text { of } \\
\text { glycerol and then } 3 \mathrm{~mL} \text { of } 0.1 \mathrm{~N} \mathrm{NaOH} \text { to neutralize the } \mathrm{pH} \\
\text { up to } 7 \text {. }\end{array}$ & Casting & Starch based biofilm & Not reported & $\begin{array}{c}\text { Rizwana Beevi et al. } \\
\text { [113] }\end{array}$ \\
\hline
\end{tabular}


Table A1. Cont.

\begin{tabular}{|c|c|c|c|c|c|}
\hline Food Waste Source & Technology and Pre-Treatment & Processing & Bioplastic Type & $\begin{array}{c}\text { Bioplastic Mechanical and } \\
\text { Physical Properties }\end{array}$ & Reference \\
\hline Carrots waste & $\begin{array}{l}\text { Carrots waste powder was dispersed in a } 5 \%(w / w) \mathrm{HCl} \\
\text { water solution at a concentration of } 50 \mathrm{mg} / \mathrm{mL} \text { under } \\
\text { vigorous stirring at } 40^{\circ} \mathrm{C} \text {. After } 12 \mathrm{~h} \text {, the viscous dispersion } \\
\text { was dialyzed using a } 3500 \text { MWCO membrane against } \\
\text { MilliQ water for } 72 \mathrm{~h} \text { and then cast on a petri dish. }\end{array}$ & Casting & $\begin{array}{l}\text { Cellulose based } \\
\text { biofilm }\end{array}$ & $\begin{array}{l}\text { Young's Modulus }(\mathrm{MPa}): \sim 1300 \\
\text { Elongation at break: } 6 \% \\
\text { Ultimate strength }(\mathrm{MPa}): \sim 37 \\
\text { Water contact angle: }>100^{\circ} \\
\text { Oxygen permeability } \\
\left(\mathrm{cm}^{3} \mu \mathrm{m} / \mathrm{m}^{2} \text { day } \mathrm{kPa}\right): 96 \times 10^{4}\end{array}$ & Perotto et al. [111] \\
\hline \multirow[b]{2}{*}{ Cassava peels } & $\begin{array}{l}100 \mathrm{~g} \text { of cassava peels were washed and soaked in sodium } \\
\text { metabisulphyte } 1 \% \text {. Then, they were crushed with } 100 \mathrm{~mL} \\
\text { of water. Slurry resulted was extracted with water (ratio of } \\
\text { 1:1) two times. The extracts were precipitated for } 3 \mathrm{~h} \text {. The } \\
\text { precipitate was dried; then } 5 \mathrm{~g} \text { were mixed with glacial } \\
\text { acetic acid } 1 \% \text {, chitosan }(20-50 \%) \text {, glycerol }(30 \%) \text {, liquid } \\
\text { smoke }(0-2 \mathrm{~mL}) \text { and stirred at } 70^{\circ} \mathrm{C} \text {. }\end{array}$ & Casting & Biocomposite & $\begin{array}{l}\text { Tensile strength }(\mathrm{MPa}) \text { : } \\
35.28-96.04 \\
\text { Elongation at break }(\%): \\
14.87-52.27 \\
\text { Water resistance }(\%): 22.68-78.40\end{array}$ & Fathanah et al. [117] \\
\hline & $\begin{array}{l}5.0 \mathrm{~g} \text { of dried cassava peels waste were mixed with } 1.5 \mathrm{~mL} \\
\text { of glycerol, } 0.5 \mathrm{~mL} \text { of kaffir lime essential oil and } 0.7 \mathrm{~g} \text { of } \\
\text { citric acid. The mixture was stirred for } 45 \mathrm{~min} \text {, and heated } \\
\text { to } 80^{\circ} \mathrm{C} \text {. Two other samples were prepared without } \\
\text { essential oil and without citric acid, respectively. }\end{array}$ & Casting & Starch based biofilm & Tensile strength (N/cm): 0.3-2.5 & Masruri et al. [115] \\
\hline Cauliflower waste & $\begin{array}{l}\text { Cauliflower waste powder was dispersed in a } 5 \%(w / w) \\
\mathrm{HCl} \text { water solution at a concentration of } 50 \mathrm{mg} / \mathrm{mL} \text { under } \\
\text { vigorous stirring at } 40{ }^{\circ} \mathrm{C} \text {. After } 12 \mathrm{~h} \text {, the viscous dispersion } \\
\text { was dialyzed using a } 3500 \text { MWCO membrane against } \\
\text { MilliQ water for } 72 \mathrm{~h} \text { and then cast on a petri dish. }\end{array}$ & Casting & $\begin{array}{l}\text { Cellulose based } \\
\text { biofilm }\end{array}$ & $\begin{array}{l}\text { Young's Modulus (MPa): } \sim 500 \\
\text { Elongation at break: } 4 \% \\
\text { Ultimate strength }(\mathrm{MPa}): \sim 7 \\
\text { Water contact angle: } \sim 80^{\circ}\end{array}$ & Perotto et al. [111] \\
\hline
\end{tabular}


Table A1. Cont.

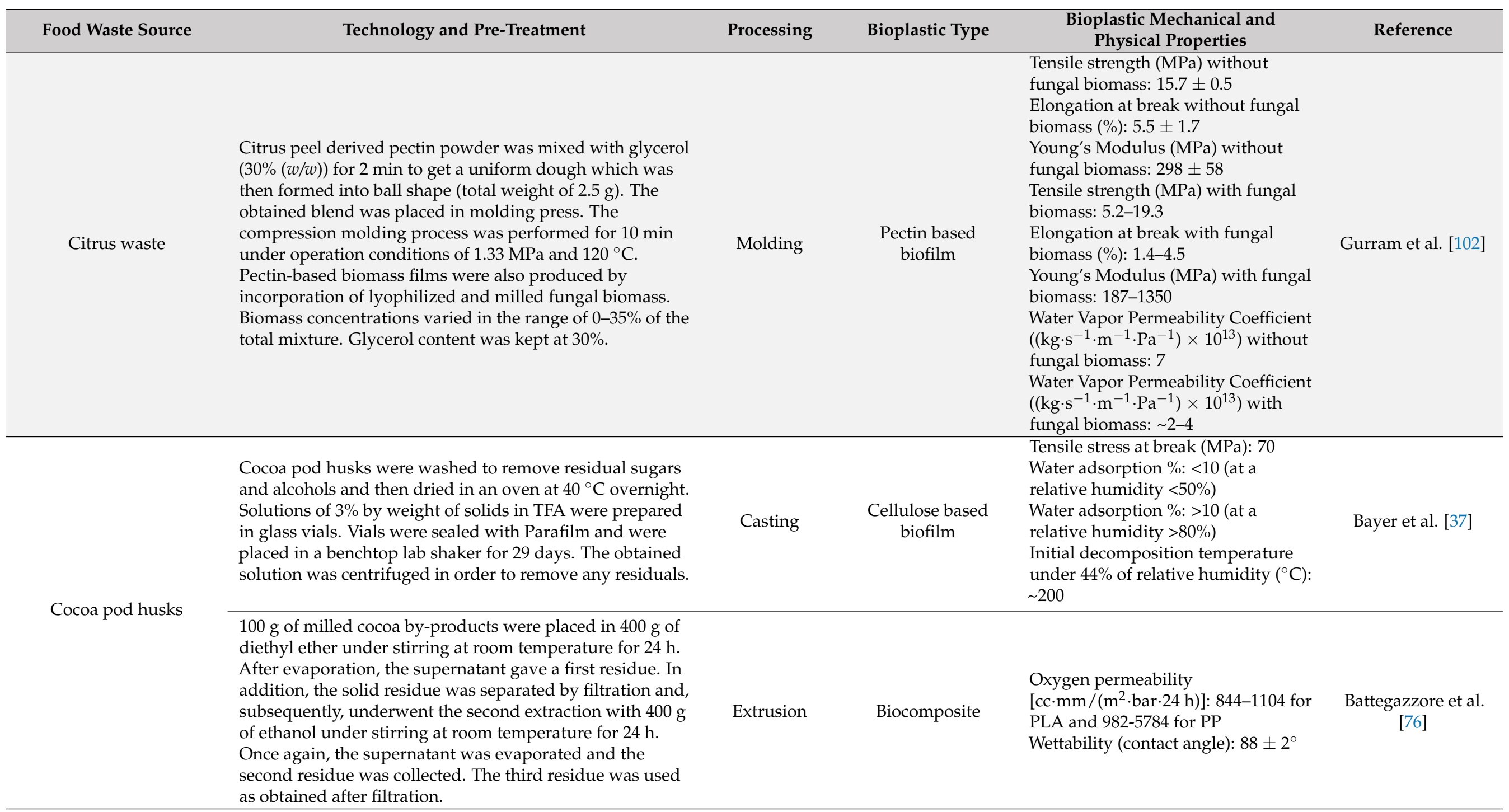


Table A1. Cont.

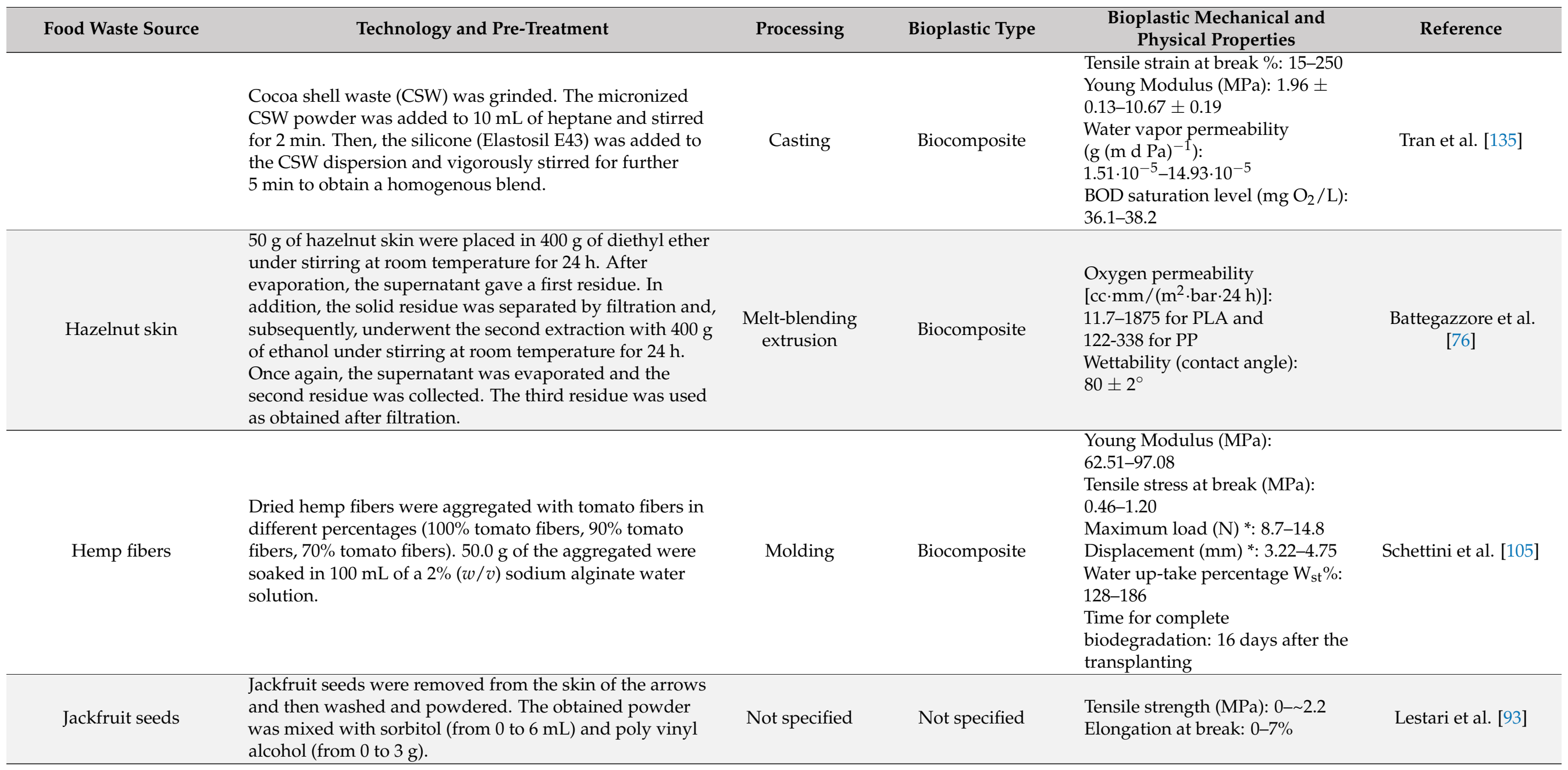


Table A1. Cont.

\begin{tabular}{|c|c|c|c|c|c|}
\hline Food Waste Source & Technology and Pre-Treatment & Processing & Bioplastic Type & $\begin{array}{c}\text { Bioplastic Mechanical and } \\
\text { Physical Properties }\end{array}$ & Reference \\
\hline Mangosteen peels & $\begin{array}{l}\text { Mangosteen peels were sun dried for about } 48 \mathrm{~h} \text { at room } \\
\text { temperature. Then, they were grinded and sieved. To } \\
\text { prepare cellulose fibers, about } 50 \mathrm{~g} \text { of the Mangosteen peels } \\
\text { powder were treated with } 700 \mathrm{~mL} \text { of } 0.1 \mathrm{M} \mathrm{NaOH} \text {, under } \\
\text { heating and stirring. Then the insoluble pulp was bleached } \\
\text { with } 500 \mathrm{~mL} \text { of } \mathrm{NaOCl} \text { buffered to a pH } 5 \text { and washed with } \\
\text { distilled water. The cellulose fibers were air dried. Then } \\
10 \mathrm{~g} \text { of fibers were hydrolyzed in } 100 \mathrm{~mL} \text { of } 95 \% \mathrm{H}_{2} \mathrm{SO}_{4} \text { at } \\
500{ }^{\circ} \mathrm{C} \text {, then diluted with distilled water, centrifuged and } \\
\text { sonicated. The resulting suspension cellulose nanocrystals } \\
(\mathrm{CNCs}) \text { were dried in a freeze drier at } 3^{\circ} \mathrm{C} \text {. CNCs were } \\
\text { mixed in different wt } \%(0-19 \%) \text { with } 10 \mathrm{~g} \text { of cassava starch, } \\
60 \mathrm{~mL} \text { of distilled water, } 5 \mathrm{~mL} \text { of vinegar and } 7 \mathrm{~mL} \text { of } \\
\text { glycerol. The mixture was stirred at } 105^{\circ} \mathrm{C} \text { up to } 200{ }^{\circ} \mathrm{C} \text {. }\end{array}$ & Casting & Biocomposite & $\begin{array}{l}\text { Tensile strength }(\mathrm{MPa}): \sim 1.3-\sim 2 \\
\text { Young's Modulus (GPa): } \sim 15-\sim 26 \\
\text { Elongation at break }(\%): \sim 15-\sim 23\end{array}$ & $\begin{array}{l}\text { Muhammad et al. } \\
\text { [103] }\end{array}$ \\
\hline Miscanthus & $\begin{array}{l}\text { Chopped } 2 \mathrm{~mm} \text { miscanthus were dried at } 80{ }^{\circ} \mathrm{C} \text { for at least } \\
24 \mathrm{~h} \text {. They were mixed with oat hull and blends of } \\
\text { PBS/PBAT }(80 / 20) \text { in the presence of peroxide }(0.02 \mathrm{phr}) \\
\text { with feeder at } 100 \mathrm{rpm} \text { and } 180^{\circ} \mathrm{C} \text {. }\end{array}$ & Extrusion & Biocomposite & $\begin{array}{l}\text { Tensile strength with 20\% } \\
\text { Mischatus fiber (MPa): } 1.0 \\
\text { Tensile strength with } 40 \% \\
\text { Mischatus fiber (MPa): } 1.0 \\
\text { Young's Modulus with } 20 \% \\
\text { Mischatus fiber (MPa): } 64 \\
\text { Young's Modulus with } 40 \% \\
\text { Mischatus fiber (MPa): } 404 \\
\text { Water absorption with } 20 \% \\
\text { Mischatus fiber: } 1-3 \% \\
\text { Water absorption with } 40 \% \\
\text { Mischatus fibre: } 1-7 \%\end{array}$ & Wu et al. [133] \\
\hline
\end{tabular}


Table A1. Cont.

\begin{tabular}{|c|c|c|c|c|c|}
\hline Food Waste Source & Technology and Pre-Treatment & Processing & Bioplastic Type & $\begin{array}{c}\text { Bioplastic Mechanical and } \\
\text { Physical Properties }\end{array}$ & Reference \\
\hline Oat Hull & $\begin{array}{l}\text { Chopped } 2 \mathrm{~mm} \text { oat hull were dried at } 80{ }^{\circ} \mathrm{C} \text { for at least } 24 \mathrm{~h} \text {. } \\
\text { They were mixed with miscanthus and blends of } \\
\text { PBS/PBAT }(80 / 20) \text { in the presence of peroxide }(0.02 \mathrm{phr}) \\
\text { with feeder at } 100 \mathrm{rpm} \text { and } 180^{\circ} \mathrm{C} \text {. }\end{array}$ & Extrusion & Biocomposite & $\begin{array}{l}\text { Tensile strength with } 20 \% \text { oat } \\
\text { hull (MPa): } 0.4 \\
\text { Tensile strength with } 40 \% \text { oat } \\
\text { hull (MPa): } 0.29 \\
\text { Young's Modulus with } 20 \% \text { oat } \\
\text { hull (MPa): } 54 \\
\text { Young's Modulus with } 40 \% \text { oat } \\
\text { hull (MPa): } 257 \\
\text { Water absorption with } 20 \% \text { oat } \\
\text { hull: } 1-5 \% \\
\text { Water absorption with } 40 \% \text { oat } \\
\text { hull: } 2-9 \%\end{array}$ & Wu et al. [133] \\
\hline \multirow[b]{2}{*}{ Orange peels } & $\begin{array}{l}\text { Dried orange peels were washed with a } \mathrm{HCl}(0.03 \mathrm{~N}) \text { at } \\
60^{\circ} \mathrm{C} \text { and agitated for } 30 \mathrm{~min} \text {. The residue was hydrolyzed } \\
\text { with } \mathrm{HCl}(0.04 \mathrm{~N}) \text { at } 90^{\circ} \mathrm{C} \text { for } 20 \mathrm{~min} \text {. Then, pectin } \\
\text { extraction was performed with hot water at } 90^{\circ} \mathrm{C} \text { and } \\
\text { agitated for } 30 \mathrm{~min} \text {. The obtained pectin jelly was mixed } \\
\text { with corn starch, layered silicates, glycerol and water; the } \\
\text { mixture was left overnight in an oven at } 70^{\circ} \mathrm{C} \text {. }\end{array}$ & $\begin{array}{l}\text { Extrusion } \\
\text { followed by } \\
\text { casting }\end{array}$ & Biocomposite & $\begin{array}{l}\text { Equilibrium recoverable } \\
\text { compliance }\left(\mathrm{m}^{2} / \mathrm{N}\right): 3.71 \times 10^{-9} \\
\text { Water vapor transmission rate } \\
\left(\mathrm{g} / \mathrm{m}^{2} \mathrm{~h}\right): 9.87 \\
\text { Oxygen gas transmission rate } \\
\left(\mathrm{mL} / \mathrm{m}^{2} \text { day): } 1366 \pm 194\right.\end{array}$ & Cokajgil et al. [100] \\
\hline & $\begin{array}{l}\text { Orange waste }(\mathrm{OW}) \text { was washed with water then dried for } \\
16 \mathrm{~h} \text { at } 40^{\circ} \mathrm{C} \text { and milled to a fine powder. A mixture of } 2 \% \\
(w / v) \text { of } \mathrm{OW} \text { powder was prepared in } 1 \%(w / v) \text { citric acid } \\
\text { solution under constant magnetic stirring at } 70{ }^{\circ} \mathrm{C} \text {. The acid } \\
\text { solution also contained } 7 \%(w / w) \text { glycerol and } 1 \text { drop of } \\
\text { organic antifoam } / 100 \mathrm{~mL} \text { solution. The suspension was } \\
\text { sieved before it was poured onto PTFE plates and dried at } \\
40^{\circ} \mathrm{C} \text {. }\end{array}$ & Casting & $\begin{array}{l}\text { Pectin and cellulose } \\
\text { based biofilm }\end{array}$ & $\begin{array}{l}\text { Tensile strengths (MPa): } 28-36 \\
\text { Time for } 90 \% \text { degradation: } \\
15 \text { days }\end{array}$ & Batori et al. [92] \\
\hline Palm empty fruit bunch & $\begin{array}{l}\text { Palm empty fruit bunch was dried, powdered and cooked } \\
\text { for } 8 \mathrm{~h} \text { at } 80{ }^{\circ} \mathrm{C} .10 \% \mathrm{NaOH} \text { solution was added and the } \\
\text { mixture was autoclaved for } 15 \text { min at } 121^{\circ} \mathrm{C} \text {. The obtained } \\
\text { mixture was added with } 10 \% \text { sodium hypochlorite } \\
\text { processed using ultrafine grinder in wet milling method. } \\
2 \% \text { cellulose was mixed with } 2 \mathrm{~L} \text { of water and passed } \\
\text { through the grinder for up to } 30 \text { cycles until a } \\
\text { nanocellulose gel was formed. } 5 \% \text { of the produced } \\
\text { nanocellulose was introduced in the Enviplast }{ }^{\circledR} \text { formula. }\end{array}$ & Extrusion & Biocomposite & $\begin{array}{l}\text { Tensile strength }\left(\mathrm{kgf} / \mathrm{cm}^{2}\right): \\
191.30 \\
\text { Elongation at break }(\%): 197.12 \\
\text { Water Vapour Transmission Rate } \\
\left(\mathrm{g} / \mathrm{m}^{2} / 24 \mathrm{~h}\right): 299.42\end{array}$ & Iriani et al. [140] \\
\hline
\end{tabular}


Table A1. Cont.

\begin{tabular}{|c|c|c|c|c|c|}
\hline Food Waste Source & Technology and Pre-Treatment & Processing & Bioplastic Type & $\begin{array}{c}\text { Bioplastic Mechanical and } \\
\text { Physical Properties }\end{array}$ & Reference \\
\hline Parsley stems & $\begin{array}{l}\text { Parsley stems were washed to remove residual sugars and } \\
\text { alcohols and then dried in an oven at } 40^{\circ} \mathrm{C} \text { overnight. } \\
\text { Solutions of } 3 \% \text { by weight of solids in TFA were prepared } \\
\text { in glass vials. Vials were sealed with Parafilm and were } \\
\text { placed in a benchtop lab shaker for } 29 \text { days. The obtained } \\
\text { solution was centrifuged in order to remove any residuals. }\end{array}$ & Casting & $\begin{array}{l}\text { Cellulose based } \\
\text { biofilm }\end{array}$ & $\begin{array}{l}\text { Tensile stress at break (MPa): } 5 \\
\text { Water adsorption } \%:<10 \text { (at a } \\
\text { relative humidity }<50 \% \text { ) } \\
\text { Water adsorption } \%:>10 \text { (at a } \\
\text { relative humidity }>80 \% \text { ) } \\
\text { Initial decomposition } \\
\text { temperature under } 44 \% \text { of } \\
\text { relative humidity }\left({ }^{\circ} \mathrm{C}\right): \sim 200\end{array}$ & Bayer et al. [37] \\
\hline $\begin{array}{l}\text { Passion fruit } \\
\text { peels }\end{array}$ & $\begin{array}{l}\text { Passion fruits peels were dried and milled to fine flour. } \\
\text { A mixture of corn and cassava starches, } 45 \text { and } 55 \% \text {, } \\
\text { respectively, was placed in a homogenizer and blended for } \\
10 \text { min with the passion fruit peel. } 2000 \mathrm{~g} \text { of the mix was } \\
\text { processed by the extruder. For the plasticizer solutions ( } 1 \mathrm{~L} \\
\text { for each treatment), different amounts of glycerol and } \\
\text { water were prepared }(60,64,70,76 \text {, and } 80 \% \text { glycerol } \\
\text { content). The extrudates were cut into } 5 \text {-g pieces, placed } \\
\text { between Teflon sheets, compressed, and molded at } 5 \text { ton } \\
\text { and } 90^{\circ} \mathrm{C} \text { for } 30 \mathrm{~s} \text {. }\end{array}$ & $\begin{array}{l}\text { Extrusion } \\
\text { followed by } \\
\text { molding }\end{array}$ & Biocomposite & $\begin{array}{l}\text { Tensile strength (MPa): } 1.6-9.0 \\
\text { Elongation at break: } 24.7-54.5 \% \\
\text { Young's Modulus }(\mathrm{MPa}): 2.4-29.9 \\
\text { Water vapor permeability } \\
\left(\mathrm{g} \cdot \mathrm{mm} / \mathrm{m}^{2} \cdot \mathrm{h} \cdot \mathrm{kPa}\right): 0.256-0.436 \\
\text { Water solubility index: } \\
50.4-68.3 \% \\
\text { Contact angle }\left(^{\circ}\right): 5.3-72.2\end{array}$ & Moro et al. [132] \\
\hline Peanut hulls & $\begin{array}{l}\text { Peanut hulls, were stored at } 4{ }^{\circ} \mathrm{C} \text {, and then reduce to } \\
\text { powder. The mixture including } 17 \mathrm{~g} \text { of peanut hulls } \\
\text { mashed to a size of around } 100 \text { microns was blended } \\
\text { minutes, gradually adding potato flour from skins }(30 \mathrm{~g}) \text {, } \\
\text { whole milk }(48 \mathrm{~mL}) \text { and glycerol }(5 \mathrm{~mL}) \text {. The mixed } \\
\text { ingredients formed a compound that was cooked in a } \\
\text { fan-assisted oven at } 180^{\circ} \mathrm{C} \text { for } 13 \mathrm{~min} \text {. }\end{array}$ & Casting & Biocomposite & Weight loss \%: $6.5 \pm 0.5$ & Troiano et al. [134] \\
\hline
\end{tabular}


Table A1. Cont.

\begin{tabular}{|c|c|c|c|c|c|}
\hline Food Waste Source & Technology and Pre-Treatment & Processing & Bioplastic Type & $\begin{array}{c}\text { Bioplastic Mechanical and } \\
\text { Physical Properties }\end{array}$ & Reference \\
\hline Pine flower waste & $\begin{array}{l}\text { Pine flowers were soaked water at } 100{ }^{\circ} \mathrm{C} \text { for } 2 \mathrm{~h} \text {, washed } \\
\text { and dried for } 24 \mathrm{~h} \text { at } 50{ }^{\circ} \mathrm{C} \text {. Then, they were grounded and } \\
\text { soaked in hot water for } 4 \mathrm{~h} \text { and roasted for } 24 \mathrm{~h} \text { at } 60{ }^{\circ} \mathrm{C} \text {. } \\
\text { For cellulose isolation, } 50 \mathrm{~g} \text { of grounded pine flower were } \\
\text { mixed with } 500 \mathrm{~mL} \text { of } 6 \% \mathrm{NaOH} \text { at } 70{ }^{\circ} \mathrm{C} \text { for } 4 \mathrm{~h} \text {. After } \\
\text { serial washing and filtration steps, } 5 \mathrm{~g} \text { of obtained cellulose } \\
\text { were mixed with } 10 \%, 30 \% \text {, and } 60 \% \text { citric acid in } 100 \mathrm{~mL} \\
\text { respectively and ultrasonicated. Then, a polyvinyl alcohol } \\
\text { (PVA) solution was prepared by mixing } 4 \% \text { PVA, } 25 \% \\
\text { glycerol, and } 71 \% \text { distilled water }(w / w) \text {, and a starch } \\
\text { solution by mixing } 3 \% \text { starch, } 12 \% \text { glycerol and } 85 \% \\
\text { distilled water }(w / w) \text {. Both solutions were mixed together } \\
\text { (PVA: starch ratio of } 80: 20(w / w)) \text { and finally } 1 \% \\
\text { nanocellulose, } 10 \% \text { turmeric extract and } 10 \% \text { natural } \\
\text { dragon fruit extract were added. }\end{array}$ & Casting & Biocomposite & Not reported & Nasihin et al. [137] \\
\hline $\begin{array}{l}\text { Pineapple } \\
\text { leaf }\end{array}$ & $\begin{array}{l}\text { Pineapple leaf were scaffed and then the fibers were cut } \\
\text { into small sizes and grinded. The grinded fibers were then } \\
\text { sieved to get the highest amount of fiber length available. } \\
\text { Then they were placed in oven for } 24 \mathrm{~h} \text { and subsequently } \\
\text { mixed with tapioca-based bioplastic resin }(70-90 \% \mathrm{w} / \mathrm{w}) \text {. } \\
\text { The mixture was first extruded into pellet at } 160^{\circ} \mathrm{C} \text {. The } \\
\text { pellets were then placed in the mold and hot pressed at } \\
160^{\circ} \mathrm{C} \text { for } 5 \text { min at } 8 \mathrm{MPa} \text {, and then cold pressed at room } \\
\text { temperature for } 5 \mathrm{~min} \text { at } 8 \mathrm{MPa} \text {. }\end{array}$ & $\begin{array}{l}\text { Extrusion } \\
\text { followed by } \\
\text { molding }\end{array}$ & Biocomposite & $\begin{array}{l}\text { Tensile Modulus }(\mathrm{GPa}) \text { : } \\
\text { 1.029-1.145 } \\
\text { Tensile strain }(\mathrm{mm} / \mathrm{mm}) \text { : } \\
0.007-0.011\end{array}$ & $\begin{array}{c}\text { Mathivanan et al. } \\
\text { [130] }\end{array}$ \\
\hline Potato peels & $\begin{array}{l}\text { Potato peels were granulated and centrifuged at } 15000 \mathrm{rpm} \\
\text { for } 20 \mathrm{~min} \text {. The supernatant was filtered and the starch was } \\
\text { obtained. } 13.5 \mathrm{~g} \text { of dried starch was extracted from } 330 \mathrm{~g} \\
\text { wet potato peels. After filtration, starch was dried at } 50{ }^{\circ} \mathrm{C} \\
\text { for } 2 \mathrm{~h} \text {. } 13.5 \mathrm{~g} \text { of starch were mixed with } 135 \mathrm{~mL} \text { of tap } \\
\text { water, } 16.2 \mathrm{~mL} \text { of vinegar, and } 10.8 \mathrm{~mL} \text { of glycerin. The } \\
\text { mixture was heated }\left(100^{\circ} \mathrm{C}\right) \text { and kept waiting at that } \\
\text { temperature for } 20 \mathrm{~min} .\end{array}$ & Casting & Starch based biofilm & $\begin{array}{l}\text { Water absorption: } 48.46 \% \text { within } \\
\text { two hours and } 83.57 \% \text { within } \\
24 \mathrm{~h} \\
\text { Time for complete } \\
\text { biodegradation: } 28 \text { days in moist } \\
\text { soil. }\end{array}$ & Arikan et al. [114] \\
\hline
\end{tabular}


Table A1. Cont.

\begin{tabular}{|c|c|c|c|c|c|}
\hline Food Waste Source & Technology and Pre-Treatment & Processing & Bioplastic Type & $\begin{array}{l}\text { Bioplastic Mechanical and } \\
\text { Physical Properties }\end{array}$ & Reference \\
\hline & $\begin{array}{l}\text { Potato peels were boiled with water and then the starch } \\
\text { was extracted from the water by filtration. The starch was } \\
\text { mixed with glycerine, vinegar and water in different ratio, } \\
\text { at } 105^{\circ} \mathrm{C} \text {. }\end{array}$ & Casting & Starch based biofilm & $\begin{array}{l}\text { Resistence to compressive stress } \\
(\mathrm{MPa}): 0.5-1.1\end{array}$ & Samer et al. [118] \\
\hline Pumpkin peels & $\begin{array}{l}1 \mathrm{~g} \text { of dry pumpkin peel residue was suspended in } 50 \mathrm{~mL} \\
\text { of } 2 \mathrm{wt} \% \mathrm{NaOH} \text { solution and stirred for } 4 \mathrm{~h} \text { at } 100{ }^{\circ} \mathrm{C} \text {. Then } \\
80 \mathrm{~mL} \text { of } 0.5 \mathrm{M} \mathrm{NaOH} \text { containing } 2 \%(\mathrm{v} / \mathrm{v}) \text { of } \mathrm{H}_{2} \mathrm{O}_{2} \text { per } \\
\text { each gram of material were added. The solution was stirred } \\
\text { during } 1 \mathrm{~h} \text {. Then, } 20 \mathrm{~mL} \text { of } 2 \mathrm{M} \mathrm{NaOH} \text { solution was added } \\
\text { and the suspension stirred during } 5 \mathrm{~h} \text { at } 55^{\circ} \mathrm{C} \text {. } \\
\text { Subsequently, the residue was washed with distilled water } \\
\text { until achieve neutral pH. Finally, the residue was filtered } \\
\text { and dried. } 12 \mathrm{~mL} \text { of [ }(\mathrm{BMIM}) \mathrm{Cl}] \text { was used per each } 0.25 \mathrm{~g} \\
\text { of material to dissolute cellulose. The isolated cellulose was } \\
\text { acetylated and } 0.02 \mathrm{~g} \text { were added to a solution of PLA } \\
(0.18 \mathrm{~g}) \text { in DCM }(25 \mathrm{~mL}) \text {. The mixture was stirred for } 1 \mathrm{~h} \text {, at } \\
50^{\circ} \mathrm{C} \text { and then it was casted. }\end{array}$ & Casting & Biocomposite & $\begin{array}{l}\text { Storage Moduls (GPa): } 1.85 \text { at } \\
40{ }^{\circ} \mathrm{C}\end{array}$ & Coto et al. [136] \\
\hline $\begin{array}{l}\text { Radicchio } \\
\text { waste }\end{array}$ & $\begin{array}{l}\text { Radicchio waste powder was dispersed in a } 5 \%(w / w) \mathrm{HCl} \\
\text { water solution at a concentration of } 50 \mathrm{mg} / \mathrm{mL} \text { under } \\
\text { vigorous stirring at } 40{ }^{\circ} \mathrm{C} \text {. After } 12 \mathrm{~h} \text {, the viscous dispersion } \\
\text { was dialyzed using a } 3500 \text { MWCO membrane against } \\
\text { MilliQ water for } 72 \mathrm{~h} \text { and then cast on a petri dish. }\end{array}$ & Casting & $\begin{array}{l}\text { Cellulose based } \\
\text { biofilm }\end{array}$ & $\begin{array}{l}\text { Young's Modulus (MPa): } \sim 200 \\
\text { Elongation at break: } 5 \% \\
\text { Ultimate strength }(\mathrm{MPa}): \sim 5 \\
\text { Water contact angle: } \sim 80^{\circ}\end{array}$ & Perotto et al. [111] \\
\hline Rice straw and hulls & $\begin{array}{l}\text { Rice hulls were washed to remove residual sugars and } \\
\text { alcohols and then dried in an oven at } 40^{\circ} \mathrm{C} \text { overnight. } \\
\text { Solutions of } 3 \% \text { by weight of solids in TFA were prepared } \\
\text { in glass vials. Vials were sealed with Parafilm and were } \\
\text { placed in a benchtop lab shaker for } 29 \text { days. The obtained } \\
\text { solution was centrifuged in order to remove any residuals. }\end{array}$ & Casting & $\begin{array}{l}\text { Cellulose based } \\
\text { biofilm }\end{array}$ & $\begin{array}{l}\text { Tensile stress at break (MPa): } 7 \\
\text { Water adsorption } \%:<10 \text { (at a } \\
\text { relative humidity }<50 \% \text { ) } \\
\text { Water adsorption } \%:>10 \text { (at a } \\
\text { relative humidity }>80 \% \text { ) } \\
\text { Initial decomposition } \\
\text { temperature under } 44 \% \text { of } \\
\text { relative humidity }\left({ }^{\circ} \mathrm{C}\right): \sim 225\end{array}$ & Bayer et al. [37] \\
\hline
\end{tabular}


Table A1. Cont.

\begin{tabular}{|c|c|c|c|c|c|}
\hline Food Waste Source & Technology and Pre-Treatment & Processing & Bioplastic Type & $\begin{array}{c}\text { Bioplastic Mechanical and } \\
\text { Physical Properties }\end{array}$ & Reference \\
\hline & $\begin{array}{l}200 \mathrm{~g} \text { of dried rice straw samples were placed in a } \\
\text { solid-liquid extractor with } 1 \mathrm{~L} \text { of Milli-Q water. Total } \\
\text { extraction was performed for approximately } 3 \mathrm{~h} \text { and with } \\
30 \text { cycles and } 12 \text { strikes per cycle and the static phase for } \\
10 \text { min. Then, } 10 \mathrm{~g} \text { of the powdered and dried rice straw, } \\
\text { previously washed and dried, was mixed with } 200 \mathrm{~mL} \text { of } \\
\text { TFA and maintained under magnetic stirring }(800 \mathrm{rpm}) \text { at } \\
\text { room temperature for } 3 \text { days and, poured into a low edge } \\
\text { crystallizing container maintained under laminar hood. }\end{array}$ & Casting & $\begin{array}{l}\text { Cellulose based } \\
\text { biofilm }\end{array}$ & $\begin{array}{l}\text { Tensile strength at break (MPa): } \\
45 \text { (dried dumbbells) } \\
\text { Elongation at break (\%): } 6.1 \\
\text { (dried dumbbells) } \\
\text { Tensile strength at break (MPa): } \\
10 \text { (wet dumbbells) } \\
\text { Elongation at break (\%): } 63 \text { (wet } \\
\text { dumbbells) } \\
\text { Water adsorption \%: } 40.7-42.6 \\
\text { Time for complete } \\
\text { biodegradation: } 105 \text { days in soil. }\end{array}$ & Bilo et al. [110] \\
\hline & $\begin{array}{l}\text { Rice straw was dried, powdered and cooked for } 8 \mathrm{~h} \text { at } \\
80^{\circ} \mathrm{C} .10 \% \mathrm{NaOH} \text { solution was added and the mixture was } \\
\text { autoclaved for } 15 \text { min at } 121{ }^{\circ} \mathrm{C} \text {. The obtained mixture was } \\
\text { added with } 10 \% \text { sodium hypochlorite processed using } \\
\text { ultrafine grinder in wet milling method. } 2 \% \text { cellulose was } \\
\text { mixed with } 2 \mathrm{~L} \text { of water and passed through the grinder for } \\
\text { up to } 30 \text { cycles until a nanocellulose gel was formed. } 5 \% \text { of } \\
\text { the produced nanocellulose was introduced in the } \\
\text { Enviplast }{ }^{\circledR} \text { formula. }\end{array}$ & Extrusion & Biocomposite & $\begin{array}{l}\text { Tensile strength }\left(\mathrm{kgf} / \mathrm{cm}^{2}\right): \\
168.36 \\
\text { Elongation at break }(\%): 156.36 \\
\text { Water Vapour Transmission Rate } \\
\left(\mathrm{g} / \mathrm{m}^{2} / 24 \mathrm{~h}\right): 301.06\end{array}$ & Iriani et al. [140] \\
\hline & $\begin{array}{l}\text { Rice straw were chopped to prepare the fibres with lengths } \\
\text { ranging from } 0.5 \text { to } 2 \mathrm{~mm} \text {. The fibers were dehydrated for } \\
24 \text { h within a vacuum oven at } 105^{\circ} \mathrm{C} \text {. } \\
\text { Three chosen polymers (PLA, Lignin, PP) were separately } \\
\text { compounded with } 20 \% \text { of rice straw fiber. }\end{array}$ & Extrusion & Biocomposite & Not reported & Dahy et al. [142] \\
\hline & $\begin{array}{l}\text { Rice waste powdered. The powder of rice waste was mixed } \\
\text { with chitosan (from } 30 \text { to } 60 \% \text { ) and glycerol (from } 0 \text { to } \\
3 \mathrm{~mL} \text { ), heated at } 50-60{ }^{\circ} \mathrm{C} \text { for } 30 \mathrm{~min} \text {. }\end{array}$ & Molding & $\begin{array}{l}\text { Cellulose based } \\
\text { biofilm }\end{array}$ & $\begin{array}{l}\text { Tensile strength (MPa): } \sim 0-60 \\
\text { Elongation at break: } 2-4 \% \\
\text { Water resistance: } 0.1-0.6 \%\end{array}$ & Lestari et al. [93] \\
\hline
\end{tabular}


Table A1. Cont.

\begin{tabular}{|c|c|c|c|c|c|}
\hline Food Waste Source & Technology and Pre-Treatment & Processing & Bioplastic Type & $\begin{array}{c}\text { Bioplastic Mechanical and } \\
\text { Physical Properties }\end{array}$ & Reference \\
\hline Sago waste & $\begin{array}{l}\text { Sago waste was soaked in hot water at } 40^{\circ} \mathrm{C} \text { for } 2 \mathrm{~h} \text { and air } \\
\text { dried. The sago waste was then treated with } 2 \% \mathrm{NaOH} \\
\text { aqueous solution at } 60{ }^{\circ} \mathrm{C} \text { for } 1 \mathrm{~h} \text {, filtered and washed. The } \\
\text { samples were dried at } 40^{\circ} \mathrm{C} \text {. The obtained fibers were } \\
\text { bleached with } \mathrm{NaClO}_{2} / \text { glacial } \mathrm{CH}_{3} \mathrm{COOH} \text { mixture at } \\
80^{\circ} \mathrm{C} \text {. Then, they were washed with distilled water and } \\
\text { dried at } 60^{\circ} \mathrm{C} \text {. The cellulose fibers were dissolved in } 10 \mathrm{~mL} \\
\text { of distilled water, stirred, ultrasonicated for } 30 \text { min and, } \\
\text { subsequently, mixed with a sago starch } 4 \%(\mathrm{w} / \mathrm{w}) \text { solution. }\end{array}$ & Casting & Biocomposite & $\begin{array}{l}\text { Tensile strength } \\
\text { (MPa):86.66-123.03 } \\
\text { Young's Modulus (MPa): } \\
\text { 1710-2958 } \\
\text { Elongation at break (\%): } \\
\text { 3.85-4.62 } \\
\text { Water absorption }(\%): ~ 100-~ 200\end{array}$ & Yacob et al. [141] \\
\hline Soy waste & $\begin{array}{l}\text { Soy waste was bleached with a solution of distilled } \\
\text { water:sodium hypochlorite }(70: 30) \text {. Then, it was separated } \\
\text { from the solvent, rinsed with distilled water and dried in } \\
\text { the oven for one hour at } 100^{\circ} \mathrm{C} \text {. Subsequently, it was } \\
\text { powdered and } 3.0 \mathrm{~g} \text { were mixed with corn starch }(9.5 \mathrm{~g}) \text {, } \\
\text { glycerol }(5 \mathrm{~mL}), \text { vinegar }(5 \mathrm{~mL}) \text { and water }(60 \mathrm{~mL}) \text {. The } \\
\text { mixing process was carried out at } 25^{\circ} \mathrm{C} \text { and } 50 \mathrm{rpm} \text { for } \\
10 \mathrm{~min} \text {. }\end{array}$ & Casting & Biocomposite & $\begin{array}{l}\text { Maximum value of force before } \\
\text { fracture }(\mathrm{N}): 6.71 \\
\text { Water absorption (\%): } 114.17\end{array}$ & $\begin{array}{l}\text { Muhammad et al. } \\
\text { [119] }\end{array}$ \\
\hline Spinach steams & $\begin{array}{l}\text { Spinach steams were washed to remove residual sugars } \\
\text { and alcohols and then dried in an oven at } 40{ }^{\circ} \mathrm{C} \text { overnight. } \\
\text { Solutions of } 3 \% \text { by weight of solids in TFA were prepared } \\
\text { in glass vials. Vials were sealed with Parafilm and were } \\
\text { placed in a benchtop lab shaker for } 29 \text { days. The obtained } \\
\text { solution was centrifuged in order to remove any residuals. }\end{array}$ & Casting & $\begin{array}{l}\text { Cellulose based } \\
\text { biofilm }\end{array}$ & $\begin{array}{l}\text { Tensile stress at break (MPa): } 1 \\
\text { Water adsorption } \%:<10 \text { (at a } \\
\text { relative humidity }<50 \% \text { ) } \\
\text { Water adsorption } \%:>10 \text { (at a } \\
\text { relative humidity }>80 \% \text { ) } \\
\text { Initial decomposition } \\
\text { temperature under } 44 \% \text { of } \\
\text { relative humidity }\left({ }^{\circ} \mathrm{C}\right): \sim 130\end{array}$ & Bayer et al. [37] \\
\hline Tea leaves waste & $\begin{array}{l}\text { Tea leaves waste were dried under vacuum at } 70{ }^{\circ} \mathrm{C} \text {, } \\
\text { grounded, and sifted. Tea waste powder (TW) was dried } \\
\text { under vacuum at } 70{ }^{\circ} \mathrm{C} \text {. TW bioplastics were synthesized } \\
\text { with } 1 \mathrm{~g} \text { of TW powder in } 20 \mathrm{~mL} \text { of } 3 \% \text { citric acid solution } \\
\text { (TW-CA) or only with water (TW-H2O). } \\
\text { Carboxymethylcellulose sodium salt at } 5 \% \text { was } \\
\text { investigated also as an additive to TW bioplastics } \\
\text { (TW-CMC). All samples were magnetically stirred in an oil } \\
\text { bath at } 60^{\circ} \mathrm{C} \text { for } 12 \mathrm{~h} \text {, then casted. }\end{array}$ & Casting & $\begin{array}{l}\text { Cellulose based } \\
\text { biofilm }\end{array}$ & $\begin{array}{l}\text { Ultimate tensile strength }(\mathrm{MPa}) \text { : } \\
2-\sim 6 \\
\text { Elongation at break: } 0.5 \%-\sim 13 \% \\
\text { Water contact angles }\left({ }^{\circ}\right) \text { : } \\
\sim 40-\sim 120\end{array}$ & Liu et al. [112] \\
\hline
\end{tabular}


Table A1. Cont.

\begin{tabular}{|c|c|c|c|c|c|}
\hline Food Waste Source & Technology and Pre-Treatment & Processing & Bioplastic Type & $\begin{array}{c}\text { Bioplastic Mechanical and } \\
\text { Physical Properties }\end{array}$ & Reference \\
\hline \multirow[t]{2}{*}{ Tomato waste } & $\begin{array}{l}\text { After the extraction of polysaccharides, carotenoids and } \\
\text { polyphenols from peels and seeds, the residual dried fibers } \\
\text { were combined with hemp fibers in different percentages } \\
\text { ( } 0 \% \text { hemp fibers, } 10 \% \text { hemp fibers, } 30 \% \text { hemp fibers). } 50.0 \mathrm{~g} \\
\text { of the aggregated fibers were soaked in } 100 \mathrm{~mL} \text { of a } 2 \% \\
(w / v) \text { sodium alginate water solution. }\end{array}$ & Molding & Biocomposite & $\begin{array}{l}\text { Young Modulus }(\mathrm{MPa}) \text { : } \\
62.51-97.08 \\
\text { Tensile stress at break }(\mathrm{MPa}) \text { : } \\
0.46-1.20 \\
\text { Maximum load }(\mathrm{N}) *: 8.7-14.8 \\
\text { Displacement }(\mathrm{mm}) *: 3.22-4.75 \\
\text { Water up-take percentage } \\
\mathrm{W}_{\mathrm{st}} \%: 128-186 \\
\text { Time for complete } \\
\text { biodegradation: } 16 \text { days after the } \\
\text { transplanting }\end{array}$ & Schettini et al. [105] \\
\hline & $\begin{array}{l}\text { Tomato pomace was subjected to alkaline hydrolysis } \\
\left(100{ }^{\circ} \mathrm{C} \text { for } 6 \mathrm{~h} \text { with a } \mathrm{NaOH} 0.5 \mathrm{M} \text { solution in water) to }\right. \\
\text { obtain cutin monomers. The supernatant was discarded } \\
\text { and the resulting solution was acidified with } \mathrm{HCl} 3 \mathrm{M} \text { up to } \\
\text { final } \mathrm{pH} 3.80 .0 \mathrm{mg} \text { of tomato pomace monomers were } \\
\text { blended with tin (II) } 2 \text {-ethylhexanoate; the mixtures were } \\
\text { placed on open carbon-doped Teflon molds and heated in } \\
\text { air inside a convention oven. }\end{array}$ & $\begin{array}{l}\text { Melt polycon- } \\
\text { densation }\end{array}$ & Aliphatic polyester & $\begin{array}{l}\text { Young Modulus (MPa): } 14-214 \\
\text { Hardness (MPa): } 1.8-26.3 \\
\text { Water contact angle: } 81^{\circ}-109^{\circ} \\
\text { Water up-take percentage: } \\
2.1-6.1 \%\end{array}$ & $\begin{array}{l}\text { Heredia-Guarreiro } \\
\text { et al. [124] }\end{array}$ \\
\hline
\end{tabular}




\section{References}

1. Plastics Europe An Analysis of European Plastics Production, Demand and Waste Data. Available online: https://www. plasticseurope.org/application/files/9715/7129/9584/FINAL_web_version_Plastics_the_facts2019_14102019.pdf (accessed on 6 April 2020).

2. Lee, A.; Liew, M.S. Ecologically derived waste management of conventional plastics. J. Mater. Cycles Waste Manag. 2020, 22, 1-10. [CrossRef]

3. Wright, S.L.; Kelly, F.J. Plastic and Human Health: A Micro Issue? Environ. Sci. Technol. 2017, 51, 6634-6647. [CrossRef] [PubMed]

4. Amodeo, C.; Sofo, A.; Tito, M.T.; Scopa, A.; Masi, S.; Pascale, R.; Mancini, I.M.; Caniani, D. Environmental factors influencing landfill gas biofiltration: Lab scale study on methanotrophic bacteria growth. J. Environ. Sci. Health Part A 2018, 53, 825-831. [CrossRef] [PubMed]

5. Caniani, D.; Caivano, M.; Pascale, R.; Bianco, G.; Mancini, I.M.; Masi, S.; Mazzone, G.; Firouzian, M.; Rosso, D. CO 2 and N $2 \mathrm{O}$ from water resource recovery facilities: Evaluation of emissions from biological treatment, settling, disinfection, and receiving water body. Sci. Total Environ. 2019, 648, 1130-1140. [CrossRef] [PubMed]

6. Caivano, M.; Pascale, R.; Mazzone, G.; Buchicchio, A.; Masi, S.; Bianco, G.; Caniani, D. $\mathrm{N}_{2} \mathrm{O}$ and $\mathrm{CO}_{2}$ Emissions from secondary settlers in WWTPs: Experimental results on full and pilot scale plants. In Lecture Notes in Civil Engineering; Springer: Cham, Switzerland, 2017; pp. 412-418.

7. Caivano, M.; Pascale, R.; Mazzone, G.; Masi, S.; Panariello, S.; Caniani, D. Disinfection unit of water resource recovery facilities: Critical issue for N2O Emission. In Lecture Notes in Civil Engineering; Springer: Cham, Switzerland, 2017; pp. 444-450.

8. Pascale, R.; Caivano, M.; Buchicchio, A.; Mancini, I.M.; Bianco, G.; Caniani, D. Validation of an analytical method for simultaneous high-precision measurements of greenhouse gas emissions from wastewater treatment plants using a gas chromatography-barrier discharge detector system. J. Chromatogr. A 2017, 1480, 62-69. [CrossRef] [PubMed]

9. Bradney, L.; Wijesekara, H.; Palansooriya, K.N.; Obadamudalige, N.; Bolan, N.S.; Ok, Y.S.; Rinklebe, J.; Kim, K.H.; Kirkham, M.B. Particulate plastics as a vector for toxic trace-element uptake by aquatic and terrestrial organisms and human health risk. Environ. Int. 2019, 131, 104937. [CrossRef]

10. Hahladakis, J.N.; Velis, C.A.; Weber, R.; Iacovidou, E.; Purnell, P. An overview of chemical additives present in plastics: Migration, release, fate and environmental impact during their use, disposal and recycling. J. Hazard. Mater. 2018, 344, 179-199. [CrossRef]

11. Lots, F.A.E.; Behrens, P.; Vijver, M.G.; Horton, A.A.; Bosker, T. A large-scale investigation of microplastic contamination: Abundance and characteristics of microplastics in European beach sediment. Mar. Pollut. Bull. 2017, 123, 219-226. [CrossRef]

12. Okunola A, A.; Kehinde I, O.; Oluwaseun, A.; Olufiropo E, A. Public and Environmental Health Effects of Plastic Wastes Disposal: A Review. J. Toxicol. Risk Assess. 2019, 5, 1-13. [CrossRef]

13. Gu, F.; Guo, J.; Zhang, W.; Summers, P.A.; Hall, P. From waste plastics to industrial raw materials: A life cycle assessment of mechanical plastic recycling practice based on a real-world case study. Sci. Total Environ. 2017, 601-602, 1192-1207. [CrossRef]

14. Yates, M.R.; Barlow, C.Y. Resources, Conservation and Recycling Life cycle assessments of biodegradable, commercial biopolymers-A critical review. Resour. Conserv. Recycl. 2013, 78, 54-66. [CrossRef]

15. Kumar, S.; Thakur, K. Bioplastics-classification, production and their potential food applications. J. Hill Agric. 2017, 8, 118. [CrossRef]

16. Polman, E.M.N.; Gruter, G.J.M.; Parsons, J.R.; Tietema, A. Comparison of the aerobic biodegradation of biopolymers and the corresponding bioplastics: A review. Sci. Total Environ. 2021, 753, 141953. [CrossRef] [PubMed]

17. Brodin, M.; Vallejos, M.; Opedal, M.T.; Area, M.C.; Chinga-Carrasco, G. Lignocellulosics as sustainable resources for production of bioplastics-A review. J. Clean. Prod. 2017, 162, 646-664. [CrossRef]

18. Karan, H.; Funk, C.; Grabert, M.; Oey, M.; Hankamer, B. Green Bioplastics as Part of a Circular Bioeconomy. Trends Plant Sci. 2019, 24, 237-249. [CrossRef]

19. Tsang, Y.F.; Kumar, V.; Samadar, P.; Yang, Y.; Lee, J.; Ok, Y.S.; Song, H.; Kim, K.H.; Kwon, E.E.; Jeon, Y.J. Production of bioplastic through food waste valorization. Environ. Int. 2019, 127, 625-644. [CrossRef]

20. Gowman, A.C.; Picard, M.C.; Lim, L.T.; Misra, M.; Mohanty, A.K. Fruit waste valorization for biodegradable biocomposite applications: A review. BioResources 2019, 14, 10047-10092. [CrossRef]

21. Maraveas, C. Production of sustainable and biodegradable polymers from agricultural waste. Polymers 2020, 12, 1127. [CrossRef]

22. Matheus, J.R.V.; Miyahira, R.F.; Fai, A.E.C. Biodegradable films based on fruit puree: A brief review. Crit. Rev. Food Sci. Nutr. 2020, 1-8. [CrossRef]

23. European Bioplastics Bioplastics Facts and Figures. Available online: https://docs.european-bioplastics.org/publications/EUBP_ Facts_and_figures.pdf (accessed on 6 April 2020).

24. Janssen, L.P.B.M.; Moscicki, L. Termoplastic Starch: A Green Material for Various Industries, 1st ed.; Janssen, P.B.M., Moscicki, L., Eds.; Wiley-VCH Verlag GmbH \& Co. KGaA: Weinheim, Germany, 2009; ISBN 9780470146835.

25. Reddy, R.L.; Reddy, V.S.; Gupta, G.A. Study of Bio-plastics As Green \& Sustainable Alternative to Plastics. Int. J. Emerg. Technol. Adv. Eng. 2013, 3, 76-81.

26. Emadian, S.M.; Onay, T.T.; Demirel, B. Biodegradation of bioplastics in natural environments. Waste Manag. 2017, 59, 526-536. [CrossRef] 
27. Ross, G.; Ross, S.; Tighe, B.J. Bioplastics: New Routes, New Products. In Brydson's Plastics Materials, 8th ed.; Elsevier: Oxford, UK, 2017; pp. 631-652. ISBN 9780323358248.

28. De Almeida Oroski, F.; Chaves Alves, F.; Bomtempo, V. Bioplastics Tipping Point: Drop-in or non-drop-in? J. Bus. Chem. 2014, 11, 42-50.

29. Xiao, B.; Zheng, M.; Pang, J.; Jiang, Y.; Wang, H.; Sun, R.; Wang, A.; Wang, X.; Zhang, T. Synthesis and Characterization of Poly(ethylene terephthalate) from Biomass-Based Ethylene Glycol: Effects of Miscellaneous Diols. Ind. Eng. Chem. Res. 2015, 54, 5862-5869. [CrossRef]

30. Chen, L.; Pelton, R.E.O.; Smith, T.M. Comparative life cycle assessment of fossil and bio-based polyethylene terephthalate (PET) bottles. J. Clean. Prod. 2016, 137, 667-676. [CrossRef]

31. Volanti, M.; Cespi, D.; Passarini, F.; Neri, E.; Cavani, F.; Mizsey, P.; Fozer, D. Terephthalic acid from renewable sources: Early-stage sustainability analysis of a bio-PET precursor. Green Chem. 2019, 21, 885-896. [CrossRef]

32. Soták, T.; Schmidt, T.; Hronec, M. Hydrogenolysis of polyalcohols in the presence of metal phosphide catalysts. Appl. Catal. A Gen. 2013, 459, 26-33. [CrossRef]

33. Yang, L.; Yan, X.; Wang, Q.; Wang, Q.; Xia, H. One-pot catalytic conversion of cellulose into polyols with Pt/CNTs catalysts. Carbohydr. Res. 2015, 404, 87-92. [CrossRef] [PubMed]

34. Pang, J.; Zheng, M.; Sun, R.; Wang, A.; Wang, X.; Zhang, T. Synthesis of ethylene glycol and terephthalic acid from biomass for producing PET. Green Chem. 2016, 18, 342-359. [CrossRef]

35. Jain, R.; Kosta, S.; Tiwari, A. Polyhydroxyalkanoates: A way to sustainable development of bioplastics. Chron. Young Sci. 2010, 1, 10-15. [CrossRef]

36. Koller, M. Poly(hydroxyalkanoates) for Food Packaging: Application and Attempts towards Implementation. Appl. Food Biotechnol. 2014, 1, 3-15.

37. Bayer, I.S.; Guzman-Puyol, S.; Heredia-Guerrero, J.A.; Ceseracciu, L.; Pignatelli, F.; Ruffilli, R.; Cingolani, R.; Athanassiou, A. Direct transformation of edible vegetable waste into bioplastics. Macromolecules 2014, 47, 5135-5143. [CrossRef]

38. Sharma, S.; Luzinov, I. Water Aided Fabrication of Whey and Albumin Plastics. J. Polym. Environ. 2012, 20, 681-689. [CrossRef]

39. Jiménez-Rosado, M.; Zarate-Ramírez, L.S.; Romero, A.; Bengoechea, C.; Partal, P.; Guerrero, A. Bioplastics based on wheat gluten processed by extrusion. J. Clean. Prod. 2019, 239, 1-8. [CrossRef]

40. Zárate-Ramírez, L.S.; Romero, A.; Bengoechea, C.; Partal, P.; Guerrero, A. Thermo-mechanical and hydrophilic properties of polysaccharide/gluten-based bioplastics. Carbohydr. Polym. 2014, 112, 16-23. [CrossRef]

41. Luengo, J.M.; García, B.; Sandoval, A.; Naharro, G.; Olivera, E.R. Bioplastics from microorganisms. Curr. Opin. Microbiol. 2003, 6, 251-260. [CrossRef]

42. Ribeiro, P.L.L.; da Silva, A.C.M.S.; Filho, J.A.M.; Druzian, J.I. Impact of different by-products from the biodiesel industry and bacterial strains on the production, composition, and properties of novel polyhydroxyalkanoates containing achiral building blocks. Ind. Crops Prod. 2015, 69, 212-223. [CrossRef]

43. Campos, M.I.; Figueiredo, T.V.B.; Sousa, L.S.; Druzian, J.I. The influence of crude glycerin and nitrogen concentrations on the production of PHA by Cupriavidus necator using a response surface methodology and its characterizations. Ind. Crops Prod. 2014, 52, 338-346. [CrossRef]

44. Chen, G.Q. A microbial polyhydroxyalkanoates (PHA) based bio- and materials industry. Chem. Soc. Rev. 2009, 38, 2434-2446. [CrossRef]

45. Costa, S.S.; Miranda, A.L.; de Morais, M.G.; Costa, J.A.V.; Druzian, J.I. Microalgae as source of polyhydroxyalkanoates (PHAs) -A review. Int. J. Biol. Macromol. 2019, 131, 536-547. [CrossRef]

46. Delgado, M.; Felix, M.; Bengoechea, C. Development of bioplastic materials: From rapeseed oil industry by products to added-value biodegradable biocomposite materials. Ind. Crops Prod. 2018, 125, 401-407. [CrossRef]

47. Muthuraj, R.; Misra, M.; Defersha, F.; Mohanty, A.K. Influence of processing parameters on the impact strength of biocomposites: A statistical approach. Compos. Part A Appl. Sci. Manuf. 2016, 83, 120-129. [CrossRef]

48. Nguyen, H.T.H.; Qi, P.; Rostagno, M.; Feteha, A.; Mille, S.A. The quest for high glass transition temperature bioplastics. J. Mater Chem. A 2013, 1, 1-38. [CrossRef]

49. Labet, M.; Thielemans, W. Synthesis of polycaprolactone: A review. Chem. Soc. Rev. 2009, 38, 3484-3504. [CrossRef] [PubMed]

50. Averous, L.; Moro, L.; Dole, P.; Fringant, C. Properties of thermoplastic blends: Starch-polycaprolactone. Polymer 2000, 41, 4157-4167. [CrossRef]

51. Bianco, G.; Agerbirk, N.; Losito, I.; Cataldi, T.R.I. Acylated glucosinolates with diverse acyl groups investigated by high resolution mass spectrometry and infrared multiphoton dissociation. Phytochemistry 2014, 100, 92-102. [CrossRef]

52. Cataldi, T.R.I.; Orlando, D.; Nardiello, D.; Rubino, A.; Bianco, G.; Abate, S.; Ciriello, R.; Guerrieri, A. A three-factor Doehlert matrix design in optimising the determination of octadecyltrimethylammonium bromide by cation-exchange chromatography with suppressed conductivity detection. Anal. Chim. Acta 2007, 597, 129-136. [CrossRef]

53. Zianni, R.; Bianco, G.; Lelario, F.; Losito, I.; Palmisano, F.; Cataldi, T.R.I. Fatty acid neutral losses observed in tandem mass spectrometry with collision-induced dissociation allows regiochemical assignment of sulfoquinovosyl-diacylglycerols. J. Mass Spectrom. 2013, 48, 205-215. [CrossRef] 
54. Bianco, G.; Zianni, R.; Anzillotta, G.; Palma, A.; Vitacco, V.; Scrano, L.; Cataldi, T.R.I. Dibenzo-p-dioxins and dibenzofurans in human breast milk collected in the area of Taranto (Southern Italy): First case study. Anal. Bioanal. Chem. 2013, 405, 2405-2410. [CrossRef]

55. Pascale, R.; Onzo, A.; Ciriello, R.; Scrano, L.; Bufo, S.A.; Bianco, G. LC/MS Based Food Metabolomics; Elsevier: Oxford, UK, 2020; ISBN 9780081005965.

56. Cataldi, T.R.I.; Bianco, G.; Abate, S.; Losito, I. Identification of unsaturated N-acylhomoserine lactones in bacterial isolates of Rhodobacter sphaeroides by liquid chromatography coupled to electrospray ionization-hybrid linear ion trap-Fourier transform ion cyclotron resonance mass spectrometry. Rapid Commun. Mass Spectrom. 2011, 25, 1817-1826. [CrossRef]

57. Pascale, R.; Bianco, G.; Cataldi, T.R.I.; Kopplin, P.S.; Bosco, F.; Vignola, L.; Uhl, J.; Lucio, M.; Milella, L. Mass spectrometry-based phytochemical screening for hypoglycemic activity of Fagioli di Sarconi beans (Phaseolus vulgaris L.). Food Chem. 2018, 242, 497-504. [CrossRef]

58. Bianco, G.; Pascale, R.; Carbone, C.F.; Acquavia, M.A.; Cataldi, T.R.I.; Schmitt-Kopplin, P.; Buchicchio, A.; Russo, D.; Milella, L. Determination of soyasaponins in Fagioli di Sarconi beans (Phaseolus vulgaris L.) by LC-ESI-FTICR-MS and evaluation of their hypoglycemic activity. Anal. Bioanal. Chem. 2018, 410, 1561-1569. [CrossRef] [PubMed]

59. Pascale, R.; Bianco, G.; Cataldi, T.R.I.; Buchicchio, A.; Losito, I.; Altieri, G.; Genovese, F.; Tauriello, A.; Di Renzo, G.C.; Lafiosca, M.C. Investigation of the Effects of Virgin Olive Oil Cleaning Systems on the Secoiridoid Aglycone Content Using High Performance Liquid Chromatography-Mass Spectrometry. JAOCS J. Am. Oil Chem. Soc. 2018, 95, 665-671. [CrossRef]

60. Pascale, R.; Acquavia, M.A.; Cataldi, T.R.I.; Onzo, A.; Coviello, D.; Bufo, S.A.; Scrano, L.; Ciriello, R.; Guerrieri, A.; Bianco, G. Profiling of quercetin glycosides and acyl glycosides in sun-dried peperoni di Senise peppers (Capsicum annuum L.) by a combination of LC-ESI (-) -MS/MS and polarity prediction in reversed-phase separations. Anal. Bioanal. Chem. 2020, 412, 3005-3015. [CrossRef] [PubMed]

61. Pascale, R.; Bianco, G.; Coviello, D.; Cristina Lafiosca, M.; Masi, S.; Mancini, I.M.; Bufo, S.A.; Scrano, L.; Caniani, D. Validation of a liquid chromatography coupled with tandem mass spectrometry method for the determination of drugs in wastewater using a three-phase solvent system. J. Sep. Sci. 2020, 43, 886-895. [CrossRef] [PubMed]

62. Onzo, A.; Acquavia, M.A.; Cataldi, T.R.I.; Ligonzo, M.; Coviello, D.; Pascale, R.; Martelli, G.; Bondoni, M.; Scrano, L.; Bianco, G. Coceth sulfate characterization by electrospray ionization tandem mass spectrometry. Rapid Commun. Mass Spectrom. 2020, 34, 1-10. [CrossRef]

63. Thakur, S.; Chaudhary, J.; Sharma, B.; Tamulevicius, S.; Thakur, V.K. ScienceDirect Sustainability of bioplastics: Opportunities and challenges. Curr. Opin. Green Sustain. Chem. 2018, 13, 68-75. [CrossRef]

64. Quarta, G. Determination of the Biobased Content in Plastics by Radiocarbon. Radiocarbon 2013, 55, 1834-1844. [CrossRef]

65. Sherwood, J.; Clark, J.H.; Farmer, T.J.; Herrero-Davila, L.; Moity, L. Recirculation: A new concept to drive innovation in sustainable product design for bio-based products. Molecules 2017, 22, 48. [CrossRef]

66. Iwata, T. Biodegradable and bio-based polymers: Future prospects of eco-friendly plastics. Angew. Chemie-Int. Ed. 2015, 54, 3210-3215. [CrossRef]

67. Lucas, N.; Bienaime, C.; Belloy, C.; Queneudec, M.; Silvestre, F.; Nava-saucedo, J. Polymer biodegradation: Mechanisms and estimation techniques. Chemosphere 2008, 73, 429-442. [CrossRef]

68. Ruggero, F.; Gori, R.; Lubello, C. Methodologies to assess biodegradation of bioplastics during aerobic composting and anaerobic digestion: A review. Waste Manag. Res. 2019, 37, 959-975. [CrossRef] [PubMed]

69. Ciriello, R.; Lo Magro, S.; Guerrieri, A. Assay of serum cholinesterase activity by an amperometric biosensor based on a co-crosslinked choline oxidase/overoxidized polypyrrole bilayer. Analyst 2018, 143, 920-929. [CrossRef] [PubMed]

70. Ciriello, R.; De Gennaro, F.; Frascaro, S.; Guerrieri, A. A novel approach for the selective analysis of L-lysine in untreated human serum by a co-crosslinked L-lysine- $\alpha$-oxidase/overoxidized polypyrrole bilayer based amperometric biosensor. Bioelectrochemistry 2018, 124, 47-56. [CrossRef] [PubMed]

71. Massardier-Nageotte, V.; Pestre, C.; Cruard-Pradet, T.; Bayard, R. Aerobic and anaerobic biodegradability of polymer films and physico-chemical characterization. Polym. Degrad. Stab. 2006, 91, 620-627. [CrossRef]

72. Kale, G.; Kijchavengkul, T.; Auras, R.; Rubino, M.; Selke, S.E.; Singh, S.P. Compostability of bioplastic packaging materials: An overview. Macromol. Biosci. 2007, 7, 255-277. [CrossRef]

73. Folino, A.; Karageorgiou, A.; Calabrò, P.S.; Komilis, D. Biodegradation of wasted bioplastics in natural and industrial environments: A review. Sustainability 2020, 12, 6030. [CrossRef]

74. Wang, K.; Wang, W.; Ye, R.; Liu, A.; Xiao, J.; Liu, Y.; Zhao, Y. Mechanical properties and solubility in water of corn starch-collagen composite films: Effect of starch type and concentrations. Food Chem. 2017, 216, 209-216. [CrossRef]

75. Oliveira, T.Í.S.; Rosa, M.F.; Ridout, M.J.; Cross, K.; Brito, E.S.; Silva, L.M.A.; Mazzetto, S.E.; Waldron, K.W.; Azeredo, H.M.C. Bionanocomposite films based on polysaccharides from banana peels. Int. J. Biol. Macromol. 2017, 101, 1-8. [CrossRef]

76. Battegazzore, D.; Bocchini, S.; Alongi, J.; Frache, A. Plasticizers, antioxidants and reinforcement fillers from hazelnut skin and cocoa by-products: Extraction and use in PLA and PP. Polym. Degrad. Stab. 2014, 108, 297-306. [CrossRef]

77. Granda, L.A.; Espinach, X.; Méndez, J.A.; Tresserras, J.; Delgado-Aguilar, M.; Mutjé, P. Semichemical fibres of Leucaena collinsii reinforced polypropylene composites: Young's Modulus analysis and fibre diameter effect on the stiffness. Compos. Part B Eng. 2016, 92, 332-337. [CrossRef] 
78. Palomba, D.; Vazquez, G.E.; Díaz, M.F. Chemometrics and Intelligent Laboratory Systems Prediction of elongation at break for linear polymers. Chemom. Intell. Lab. Syst. 2014, 139, 121-131. [CrossRef]

79. Sanjay, M.R.; Arpitha, G.R.; Yogesha, B. Study on Mechanical Properties of Natural-Glass Fibre Reinforced Polymer Hybrid Composites: A Review. Mater. Today Proc. 2015, 2, 2959-2967. [CrossRef]

80. Suderman, N.; Isa, M.I.N.; Sarbon, N.M. Food Bioscience The effect of plasticizers on the functional properties of biodegradable gelatin-based film: A review. Food Biosci. 2018, 24, 111-119. [CrossRef]

81. Vieira, G.M.A.; da Silva, A.M.; dos Santos, L.O.; Beppu, M.M. Natural-based plasticizers and biopolymer films: A review. Eur. Polym. J. 2011, 47, 254-263. [CrossRef]

82. Suyatma, N.E.; Tighzert, L.; Copinet, A.; Coma, V. Effects of hydrophilic plasticizers on mechanical, thermal, and surface properties of chitosan films. J. Agric. Food Chem. 2005, 53, 3950-3957. [CrossRef]

83. Di Gioia, L.; Guilbert, S. Corn protein-based thermoplastic resins: Effect of some polar and amphiphilic plasticizers. J. Agric. Food Chem. 1999, 47, 1254-1261. [CrossRef]

84. Santosa, F.X.B.; Padua, G.W. Tensile properties and water absorption of zein sheets plasticized with oleic and linoleic acids. J. Agric. Food Chem. 1999, 47, 2070-2074. [CrossRef]

85. Saberi, B.; Chockchaisawasdee, S.; Golding, J.B.; Scarlett, C.J.; Stathopoulos, C.E. Physical and mechanical properties of a new edible film made of pea starch and guar gum as affected by glycols, sugars and polyols. Int. J. Biol. Macromol. 2017, 104, 345-359. [CrossRef]

86. Ghasemlou, M.; Khodaiyan, F.; Oromiehie, A. Physical, mechanical, barrier, and thermal properties of polyol-plasticized biodegradable edible film made from kefiran. Carbohydr. Polym. 2011, 84, 477-483. [CrossRef]

87. Tihminlioglu, F.; Atik, I.D.; Ozen, B. Water vapor and oxygen-barrier performance of corn-Zein coated polypropylene films. J. Food Eng. 2010, 96, 342-347. [CrossRef]

88. Gustafsson, J.; Landberg, M.; Bátori, V.; Åkesson, D.; Taherzadeh, M.J.; Zamani, A. Development of bio-based films and 3D objects from apple pomace. Polymers 2019, 11, 289. [CrossRef] [PubMed]

89. Yaradoddi, J.; Patil, V.; Ganachari, S.; Banapurmath, N.; Hunashyal, A.; Shettar, A. Biodegradable plastic production from fruit waste material and its sustainable use for green apllications. Int. J. Pharm. Res. Allied Sci. 2016, 5, 56-65.

90. Sultan, N.F.K.; Johari, W.L.W. The Development of Banana Peel/Corn Starch Bioplastic Film: A Preliminary Study. Bioremediat. Sci. Technol. Res. 2017, 5, 12-17.

91. Faradilla, R.H.F.; Lee, G.; Roberts, J.; Martens, P.; Stenzel, M.; Arcot, J. Effect of glycerol, nanoclay and graphene oxide on physicochemical properties of biodegradable nanocellulose plastic sourced from banana pseudo-stem. Cellulose 2018, 25, 399-416. [CrossRef]

92. Bátori, V.; Jabbari, M.; Åkesson, D.; Lennartsson, P.R.; Taherzadeh, M.J.; Zamani, A. Production of Pectin-Cellulose Biofilms: A New Approach for Citrus Waste Recycling. Int. J. Polym. Sci. 2017, 2017, 1-10. [CrossRef]

93. Lestari, R.A.S.; Kasmiyatun, M.; Dermawan, K.; Aini, A.N.; Riyati, N.; Putri, F.R. Bioplastic from Jackfruit Seeds and Rice. IOP Conf. Ser. Mater. Sci. Eng. 2020, 835, 1-10. [CrossRef]

94. Sun, S.; Song, Y.; Zheng, Q. Morphology and mechanical properties of thermo-molded bioplastics based on glycerol-plasticized wheat gliadins. J. Cereal Sci. 2008, 48, 613-618. [CrossRef]

95. Caner, C.; Vergano, P.J.; Wiles, J.L. Chitosan film mechanical and permeation properties as affected by acid, plasticizer, and storage. J. Food Sci. 1998, 63, 1049-1053. [CrossRef]

96. Aguilar, J.M.; Bengoechea, C.; Pérez, E.; Guerrero, A. Effect of different polyols as plasticizers in soy based bioplastics. Ind. Crops Prod. 2020, 153, 1-9. [CrossRef]

97. Alonso-González, M.; Ramos, M.; Bengoechea, C.; Romero, A.; Guerrero, A. Evaluation of Composition on Processability and Water Absorption of Wheat Gluten-Based Bioplastics. J. Polym. Environ. 2020, 1-10. [CrossRef]

98. Bashir, A.S.M.; Manusamy, Y. Recent Developments in Biocomposites Reinforced with Natural Biofillers from Food Waste. Polym. Plast. Technol. Eng. 2015, 54, 87-99. [CrossRef]

99. Cinar, S.O.; Chong, Z.K.; Kucuker, M.A.; Wieczorek, N.; Cengiz, U.; Kuchta, K. Bioplastic Production from Microalgae: A Review. Int. J. Environ. Res. Public Health 2020, 17, 3842. [CrossRef]

100. Çokaygil, Z.; Banar, M.; Seyhan, A.T. Orange peel-derived pectin jelly and corn starch-based biocomposite film with layered silicates. J. Appl. Polym. Sci. 2014, 131, 1-12. [CrossRef]

101. González-Gutiérrez, J.; Partal, P.; García-Morales, M.; Gallegos, C. Effect of processing on the viscoelastic, tensile and optical properties of albumen/starch-based bioplastics. Carbohydr. Polym. 2011, 84, 308-315. [CrossRef]

102. Gurram, R.; Souza Filho, P.F.; Taherzadeh, M.J.; Zamani, A. A Solvent-Free Approach for Production of Films from Pectin and Fungal Biomass. J. Polym. Environ. 2018, 26, 4282-4292. [CrossRef]

103. Muhammad, A.; Roslan, A.; Sanusi, S.N.A.; Shahimi, M.Q.; Nazari, N.Z. Mechanical properties of bioplastic form cellulose nanocrystal (CNC) mangosteen peel using glycerol as plasticizer. J. Phys. Conf. Ser. 2019, 1349, 1-8. [CrossRef]

104. Oliveira, T.Í.S.; Rosa, M.F.; Cavalcante, F.L.; Pereira, P.H.F.; Moates, G.K.; Wellner, N.; Mazzetto, S.E.; Waldron, K.W.; Azeredo, H.M.C. Optimization of pectin extraction from banana peels with citric acid by using response surface methodology. Food Chem. 2016, 198, 113-118. [CrossRef] [PubMed] 
105. Schettini, E.; Santagata, G.; Malinconico, M.; Immirzi, B.; Scarascia Mugnozza, G.; Vox, G. Recycled wastes of tomato and hemp fibres for biodegradable pots: Physico-chemical characterization and field performance. Resour. Conserv. Recycl. 2013, 70, 9-19. [CrossRef]

106. Jha, A.; Kumar, A. Biobased technologies for the efficient extraction of biopolymers from waste biomass. Bioprocess Biosyst. Eng. 2019, 42, 1893-1901. [CrossRef]

107. Pingali, S.V.; Urban, V.S.; Heller, W.T.; McGaughey, J.; O’Neill, H.; Foston, M.B.; Li, H.; Wyman, C.E.; Myles, D.A.; Langan, P.; et al. Understanding Multiscale Structural Changes during Dilute Acid Pretreatment of Switchgrass and Poplar. ACS Sustain. Chem. Eng. 2017, 5, 426-435. [CrossRef]

108. Wang, S.; Lu, A.; Zhang, L. Recent advances in regenerated cellulose materials. Prog. Polym. Sci. 2016, 53, 169-206. [CrossRef]

109. Zhao, H.; Holladay, J.E.; Kwak, J.H.; Zhang, Z.C. Inverse Temperature-Dependent Pathway of Cellulose Decrystallization in Trifluoroacetic Acid. J. Phys. Chem. B 2007, 111, 5295-5300. [CrossRef] [PubMed]

110. Bilo, F.; Pandini, S.; Sartore, L.; Depero, L.E.; Gargiulo, G.; Bonassi, A.; Federici, S.; Bontempi, E. A sustainable bioplastic obtained from rice straw. J. Clean. Prod. 2018, 200, 357-368. [CrossRef]

111. Perotto, G.; Ceseracciu, L.; Simonutti, R.; Paul, U.C.; Guzman-Puyol, S.; Tran, T.N.; Bayer, I.S.; Athanassiou, A. Bioplastics from vegetable waste: Via an eco-friendly water-based process. Green Chem. 2018, 20, 894-902. [CrossRef]

112. Liu, M.; Arshadi, M.; Javi, F.; Lawrence, P.; Davachi, S.M.; Abbaspourrad, A. Green and facile preparation of hydrophobic bioplastics from tea waste. J. Clean. Prod. 2020, 276, 1-10. [CrossRef]

113. Rizwana Beevi, K.; Sameera Fathima, A.R.; Thahira Fathima, A.I.; Thameemunisa, N.; Noorjahan, C.M.; Deepika, T. Bioplastic Synthesis Using Banana Peels And Potato Starch And Characterization. Int. J. Sci. Technol. Res. 2020, 9, $1809-1814$.

114. Arikan, E.B.; Bilgen, H.D. Production of bioplastic from potato peel waste and investigation of its biodegradability. Int. Adv. Res. Eng. J. 2019, 03, 093-097. [CrossRef]

115. Masruri, M.; Azhar, A.Z.; Rosyada, I.; Febrianto, A. The effect of kaffir lime (Citrus hystrix DC) essential oil on bioplastic derived from cassava peel waste. J. Phys. Conf. Ser. 2019, 1374, 1-6. [CrossRef]

116. Dasumiati; Saridewi, N.; Malik, M. Food packaging development of bioplastic from basic waste of cassava peel (manihot uttilisima) and shrimp shell. IOP Conf. Ser. Mater. Sci. Eng. 2019, 602, 1-9. [CrossRef]

117. Fathanah, U.; Lubis, M.R.; Nasution, F.; Masyawi, M.S. Characterization of bioplastic based from cassava crisp home industrial waste incorporated with chitosan and liquid smoke. IOP Conf. Ser. Mater. Sci. Eng. 2018, 334, 1-8. [CrossRef]

118. Samer, M.; Khalefa, Z.; Abdelall, T.; Moawya, W.; Farouk, A.; Abdelaziz, S.; Soliman, N.; Salah, A.; Gomaa, M.; Mohamed, M. Bioplastics production from agricultural crop residues. Agric. Eng. Int. CIGR J. 2019, 21, 190-194.

119. Muhammad, A.; Rashidi, A.R.; Roslan, A.; Idris, S.A. Development of bio based plastic materials for packaging from soybeans waste. AIP Conf. Proc. 2017, 1885, 1-8. [CrossRef]

120. Emaga, T.H.; Robert, C.; Sebastien, N.R.; Wathelet, B.; Paquot, M. Dietary fibre components and pectin chemical features of peels during ripening in banana and plantain varieties. Bioresour. Technol. 2008, 99, 4346-4354. [CrossRef] [PubMed]

121. Mohnen, D. Pectin structure and biosynthesis. Curr. Opin. Plant Biol. 2008, 11, 266-277. [CrossRef]

122. Khan, A.; Khan, R.A.; Salmieri, S.; Le Tien, C.; Riedl, B.; Bouchard, J.; Chauve, G.; Tan, V.; Kamal, M.R.; Lacroix, M. Mechanical and barrier properties of nanocrystalline cellulose reinforced chitosan based nanocomposite films. Carbohydr. Polym. 2012, 90, 1601-1608. [CrossRef]

123. Olsson, E.; Hedenqvist, M.S.; Johansson, C.; Järnström, L. Influence of citric acid and curing on moisture sorption, diffusion and permeability of starch films. Carbohydr. Polym. 2013, 94, 765-772. [CrossRef]

124. Heredia-Guerrero, J.A.; Caputo, G.; Guzman-Puyol, S.; Tedeschi, G.; Heredia, A.; Ceseracciu, L.; Benitez, J.J.; Athanassiou, A. Sustainable polycondensation of multifunctional fatty acids from tomato pomace agro-waste catalyzed by tin (II) 2-ethylhexanoate. Mater. Today Sustain. 2019, 3, 1-10. [CrossRef]

125. Domínguez, E.; Heredia-Guerrero, J.A.; Heredia, A. Plant cutin genesis: Unanswered questions. Trends Plant Sci. 2015, 20, 551-558. [CrossRef]

126. Deng, M.; Zhang, G.; Zeng, Y.; Pei, X.; Huang, R.; Lin, J. Simple process for synthesis of layered sodium silicates using rice husk ash as silica source. J. Alloys Compd. 2016, 683, 412-417. [CrossRef]

127. Mohanty, A.K.; Misra, M.; Hinrichsen, G. Biofibres, biodegradable polymers and biocomposites: An overview. Macromol. Mater. Eng. 2000, 276-277, 1-24. [CrossRef]

128. Ashori, A.; Nourbakhsh, A. Bio-based composites from waste agricultural residues. Waste Manag. 2010, 30, 680-684. [CrossRef] [PubMed]

129. Russo, R.; Malinconico, M.; Santagata, G. Effect of cross-linking with calcium ions on the physical properties of alginate films. Biomacromolecules 2007, 8, 3193-3197. [CrossRef] [PubMed]

130. Mathivanan, D.; Norfazilah, H.; Siregar, J.P.; Rejab, M.R.M.; Bachtiar, D.; Cionita, T. The study of mechanical properties of pineapple leaf fibre reinforced tapioca based bioplastic resin composite. MATEC Web Conf. 2016, 74, 1-4. [CrossRef]

131. Yapo, B.M.; Koffi, K.L. Dietary fiber components in yellow passion fruit rind-A potential fiber source. J. Agric. Food Chem. 2008, 56, 5880-5883. [CrossRef] [PubMed]

132. Moro, T.M.A.; Ascheri, J.L.R.; Ortiz, J.A.R.; Carvalho, C.W.P.; Meléndez-Arévalo, A. Bioplastics of Native Starches Reinforced with Passion Fruit Peel. Food Bioprocess Technol. 2017, 10, 1798-1808. [CrossRef] 
133. Wu, F.; Misra, M.; Mohanty, A.K. Sustainable green composites from biodegradable plastics blend and natural fibre with balanced performance: Synergy of nano-structured blend and reactive extrusion. Compos. Sci. Technol. 2020, 200, 1-8. [CrossRef]

134. Troiano, M.; Santulli, C.; Roselli, G.; Di Girolami, G.; Cinaglia, P.; Gkrilla, A. DIY Bioplastics from Peanut Hulls Waste in a Starch-Milk Based Matrix. FME Trans. 2018, 46, 503-512. [CrossRef]

135. Tran, T.N.; Heredia-Guerrero, J.A.; Mai, B.T.; Ceseracciu, L.; Marini, L.; Athanassiou, A.; Bayer, I.S. Bioelastomers Based on Cocoa Shell Waste with Antioxidant Ability. Adv. Sustain. Syst. 2017, 1, 1700002. [CrossRef]

136. Côto, T.; Moura, I.; de Sá, A.; Vilarinho, C.; Machado, A.V. Sustainable materials based on cellulose from food sector agro-wastes. J. Renew. Mater. 2018, 6, 688-696. [CrossRef]

137. Nasihin, Z.D.; Masruri, M.; Warsito, W.; Srihardyastutie, A. Preparation of Nanocellulose Bioplastic with a Gradation Color of Red and Yellow. IOP Conf. Ser. Mater. Sci. Eng. 2020, 833, 1-6. [CrossRef]

138. Azieyanti, N.A.; Amirul, A.; Othman, S.Z.; Misran, H. Mechanical and Morphology Studies of Bioplastic-Based Banana Peels. J. Phys. Conf. Ser. 2020, 1529, 1-6. [CrossRef]

139. Sharif Hossain, A.B.M.; Ibrahim, N.A.; AlEissa, M.S. Nano-cellulose derived bioplastic biomaterial data for vehicle bio-bumper from banana peel waste biomass. Data Brief 2016, 8, 286-294. [CrossRef] [PubMed]

140. Iriani, E.S.; Permana, A.W.; Yuliani, S.; Kailaku, S.I.; Sulaiman, A.A. The effect of agricultural waste nanocellulose on the properties of bioplastic for fresh fruit packaging. IOP Conf. Ser. Earth Environ. Sci. 2019, 309, 1-7. [CrossRef]

141. Yacob, N.; Yusof, M.R.; Mohamed, A.Z.; Badri, K.H. Effect of cellulose fiber loading on the properties of starch-based films. AIP Conf. Proc. 2019, 2111, 1-7. [CrossRef]

142. Dahy, H. Efficient Fabrication of Sustainable Building Products from Annually Generated Non-wood Cellulosic Fibres and Bioplastics with Improved Flammability Resistance. Waste Biomass Valoriz. 2019, 10, 1167-1175. [CrossRef]

143. Lu, S.-T.; Hamerton, I. Recent developments in the chemistry of halogen-free flame retardant polymers. Prog. Polym. Sci. 2002, 27, 1661-1712. [CrossRef]

144. Shruti, V.C.; Kutralam-Muniasamy, G. Bioplastics: Missing link in the era of Microplastics. Sci. Total Environ. 2019, 697, 134139. [CrossRef]

145. Bhagwat, G.; Gray, K.; Wilson, S.P.; Muniyasamy, S.; Vincent, S.G.T.; Bush, R.; Palanisami, T. Benchmarking Bioplastics: A Natural Step Towards a Sustainable Future. J. Polym. Environ. 2020, 28, 3055-3075. [CrossRef]

146. Hottle, T.A.; Bilec, M.M.; Landis, A.E. Sustainability assessments of bio-based polymers. Polym. Degrad. Stab. 2013, 98, 1898-1907. [CrossRef]

147. Kakadellis, S.; Harris, Z.M. Don't scrap the waste: The need for broader system boundaries in bioplastic food packaging life-cycle assessment-A critical review. J. Clean. Prod. 2020, 274, 122831. [CrossRef]

148. Panuccio, M.R.; Attinà, E.; Basile, C.; Mallamaci, C.; Muscolo, A. Use of Recalcitrant Agriculture Wastes to Produce Biogas and Feasible Biofertilizer. Waste Biomass Valoriz. 2016, 7, 267-280. [CrossRef]

149. Heckman, J.H. Food packaging regulation in the United States and the European Union. Regul. Toxicol. Pharmacol. 2005, 42, 96-122. [CrossRef] [PubMed]

150. Peelman, N.; Ragaert, P.; De Meulenaer, B.; Adons, D.; Peeters, R.; Cardon, L.; Van Impe, F.; Devlieghere, F. Application of bioplastics for food packaging. Trends Food Sci. Technol. 2013, 32, 128-141. [CrossRef]

151. Malinconico, M.; Immirzi, B.; Santagata, G.; Schettini, E.; Vox, G.; Mugnozza, G.S. An overview on innovative biodegradable materials for agricultural applications. In Progress in Polymer Degradation and Stability Research; Moeller, H.W., Ed.; Nova Science Publishers: New York, NY, USA, 2008; pp. 69-114. ISBN 9781600218286. 